\title{
Mantle plumes, associated intraplate tectono- magmatic processes and ore systems
}

\author{
Geological Survey of Western Australia, 100 Plain Street, East Perth, WA 6004, Australia.E-mail:franco.pirajno@doir.wa.gov.au
}

\begin{abstract}
Intraplate tectonic and magmatic phenomena are linked to deep mantle plumes and asthenospheric upwellings. Resulting magmas, which include layered mafic-ultramafic intrusions, sill complexes, continental and oceanic flood lavas, giant dyke swarms and anorogenic A-type granitic rocks, are responsible, directly or indirectly, for a large number of intraplate and anorogenic ore systems. These ore systems can be considered in terms of 1) magma-associated, such as orthomagmatic $\mathrm{Ni}-\mathrm{Cu}$ $P G E, C r$ in mafic-ultramafic rocks and magmatichydrothermal ore systems in anorogenic A-type magmas (e. g. greisen $\mathrm{Sn}-\mathrm{W}, \mathrm{Fe}$ oxide-Cu-Au); and 2) hydrothermal systems powered by the large thermal energy that results from the emplacement of plume-derived melts into the crust. These hydrothermal ore systems include low-S epithermal, porphyry, VMS and Carlin style deposits.
\end{abstract}

\section{Introduction}

Intraplate tectono-magmatic phenomena and associated ore systems, including the emplacement of layered intrusions, giant dyke swarms, anorogenic felsic-intermediate magmatism, oceanic plateaux, rifting processes, basin formation, and geomorphological features are linked to mantle dynamics. In this contribution, mantle dynamics refer to upwelling mantle material or mantle plumes that originate either from the $670 \mathrm{~km}$ discontinuity (shallow plumes) or from the core-mantle boundary (deep plumes). Considerable support for deep mantle plumes comes from high resolution seismic tomography, which has shown with increasing clarity vertical cross-sections of Pwave velocity images to depths greater than $2500 \mathrm{~km}$ (Montelli et al., 2004; Zhao, 2004; Nolet et al., 2006). Like plate tectonics, the theory of mantle plumes is a powerful concept that provides testable models for intraplate tectonic, magmatism, volcanism and ore-forming processes. However, there are alternative views that explain particular aspects of intraplate volcanism (Foulger et al., 2005). These include upwellings of asthenospheric melt or shallow mantle plume, during extensional processes commonly resulting from delamination of the lithosphere or from slab roll back or breakoff (Elkins-Tanton, 2005).

Regions of intraplate magmatism are anorogenic in nature and characterised by geochemical and isotopic signatures indicative of mantle sources. Degree of partial melting, volatile contents, nature of mantle material (enriched, depleted, entraining fragments of subducted slabs) control the products of plume magmatism. For this reason, plume-related rocks are isotopically heterogeneous and commonly characterized by nearly flat chondrite-normalised REE patterns. Ocean island basalts and continental flood basalts have some- what monotonous major and trace element compositions, but with distinctive trace element patterns and ratios (e. g. $\mathrm{Nb} / \mathrm{Y}, \mathrm{Zr} / \mathrm{Y}$ ) as compared to mid-ocean ridge and volcanic arc basaltic rocks, although overlaps do occur due to the above-mentioned entrainment of slab materials into ascending plumes (Condie, 2003). Intraplate basalts are enriched in the most incompatible elements $(\mathrm{Rb}, \mathrm{Ba}, \mathrm{Th}$, $\mathrm{K}, \mathrm{Ta}, \mathrm{Nb}$ ) , with positive $\mathrm{Nb}-\mathrm{Ta}$ anomalies for ocean islands basalts, whereas most continental flood basalts have small negative $\mathrm{Nb}-\mathrm{Ta}$ anomalies (Condie, 2001; Reiners, 2002). Good isotopic tracers of mantle plumes include ${ }^{187} \mathrm{Os} /{ }^{188} \mathrm{Os},{ }^{87} \mathrm{Sr} /{ }^{86} \mathrm{Sr},{ }^{143} \mathrm{Nd} /{ }^{144} \mathrm{Nd}$, ${ }^{206} \mathrm{~Pb} /{ }^{204} \mathrm{~Pb}$ ratios (Rogers et al. 2000; Hofmann, 1997) and noble gases isotope systematics such as ${ }^{3} \mathrm{He} /{ }^{4} \mathrm{He}$ and $\mathrm{Ne}$ (e.g. Samuel and Farnetani, 2003; Ballentine et al., 2005).

In this paper, I draw from Pirajno (2000 and 2004a) and present an overview of the relationships between mantle dynamics, intraplate tectono-magmatic processes and their associated ore systems. This overview focuses on direct links, proxied by the emplacement of mafic-ultramafic magmas (e.g. PGE and Ni-Cu sulphides associated with flood basalts) and indirectly in rift systems created by the impact of mantle plumes onto the base of the continental lithosphere. Thermal anomalies associated with mantle plumes constitute powerful heat sources in the crust. These may be responsible for the inception of crustal scale hydrothermal circulation and high$\mathrm{T}$ and low-P metamorphism, which may result in a wide range of ore deposits in plume-related rift systems. Therefore, we can consider mantle plume-related ore systems in terms of two end-members: 1) magma-associated, which includes orthomagmatic and intrusionrelated magmatic-hydrothermal systems and;2) giant hydrothermal systems powered by the thermal energy linked to the cooling of anorogenic magmas in the crust. Orthomagmatic sulphide ore deposits are typically hosted by mafic-ultramafic layered intrusions, dykes, sill complexes, continental flood basalts, and Archaean komatiite fields. Anorogenic intrusions (e.g. A-type granites) host or are associated with ore deposits including both magmatic-hydrothermal and hydrothermal types. Kimberlites, lamproites and carbonatites are included in anorogenic magmatism. A wide range of hydrothermal ore systems can be linked with rifting processes and intraplate magmatism caused by deep mantle plumes or upwelling asthenopheric mantle.

\section{Mantle dynamics and associated tectonic, magmatic and geomorpholgical features}

Campbell and Davies (2006 and references therein) and Campbell (2005) discussed the mantle plume hypothesis. Here I provide an overview of mantle plumes with some emphasis on associated tectonic and magmatic processes, in order to set the background for those ore systems that are linked to these mantle processes. Tectonic, magmatic and geomorphological effects of mantle upwellings are summarised in Table 1 (Pirajno, 2004a). Ore systems that are directly or indirectly linked with mantle processes are discussed in the next section. Mantle plume activities in the geological record are comprehensively treated in Ernst and Buchan (2003) 
Table 1 Main geological features and processes associated with mantle plumes.

\section{\begin{tabular}{l|l} 
Tectonic, magmatic and geomorphological effects & Selected examples
\end{tabular}}

Doming of the crust; uplift and subsidence: in doming of the crust. Subsidence follows due to thermal decay, forming sedimentary basins.
The impact of a mantle plume onto the base of the lithosphere results

Recent to modern examples of mantle-plume induced topographic uplifts, include the East African plateau (Afar hotspot), the Mongolian plateau and the swells in the central Pacific Ocean. The great escarpments of southern Africa, a major physiographic feature in the subcontinent, were formed in response to uplift linked to the Paraná -Etendeka and the Karoo mantle plumes. The Centralian Superbasin in Australia was probably formed as a large sag resulting from crustal thinning over a mantle plume.

\section{Intracontinental rifting:}

Doming can result in rupture and rifting, with development of triple junctions.

Basin-and-Range style rifts can also develop.

Examples of continental rifts, all associated with intraplate igneous activity, include the East African Rift System; the Permo-Triassic rift system developed between the East European and Siberian Cratons; the 1.1 Ga Mid-continent rift system in the USA; the 1.0-0.7 Ga Damara-Irumide rift systems that developed between the Congo and Kalahari Cratons in southern Africa.

Basin-and Range style rifting in the US and eastern China

\section{Continental breakups and related passive margins:}

Mantle plumes cause stress during uplift as well as thermal thinning due to conductive heat transfer. Extension and rifting may lead to the formation of triple junctions, continental break up and eventually to sea floor spreading.

Passive margins and associated volcano-sedimentary prisms evolve from continental rifts and the opening of oceans

Mantle plume magmatism: (see Ernst and Buchan 2001, for a full list of mantle plume magmatism since $3.5 \mathrm{Ga}$ ):

- Layered intrusions

- Dyke swarms

- Oceanic plateaux

- Seaward-dipping reflectors

- Sill complexes

- Continental flood basalts

- Silicic large igneous provinces (see Bryan, this issue)

- Anorogenic igneous complexes

- Carbonatites, kimberlites, lamproites
Examples of continental breakup are provided by the Atlantic Ocean and North Sea: the South Atlantic (Tristan da Cunha plume; 137-127 Ma Paraná -Etendeka igneous province, the North Atlantic (Iceland plume and the 60-54 Ma North Atlantic Igneous Province), the Central Atlantic (Cape Verde? plume) and 200 Ma Central Atlantic Magmatic Province. An example of plume-related passive margins is the southwest African (Namibian) margin (Tristan da Cunha hotspot).

Examples:

Layered intrusions: Windimurra (2.8 Ga, West. Australia), Stillwater (2.7Ga, USA), Bushveld Complex (2.06 Ga, South Africa), Giles Complex (1.1 Ga, central Australia), Duluth (1.1 Ga, USA), Skaergaard (0.06 Ga, Greenland).

Dyke swarms: Widgiemooltha (2.4 Ga, West. Australia), Matachewan (2.4-2.5 Ga, Canada), Mackenzie (1.26 Ga, Canada), Gairdner (0.83 Ga, central Australia), Okavango (0.18 Ga, Botswana).

Oceanic plateaux: Kerguelen, Ontong-Java, Caribeean-Colombia.

Seaward dipping reflectors: numerous examples in the Atlantic Ocean (west coast of Africa, north American eastern seaboard, the North Sea).

Sill complexes: Noril'sk-Talnakh; central Western Australia (Warakurna LIP).

Continental flood basalts: Ventersdorp, Fortescue, Karoo, Siberian Traps, Emeishan, Paraná -Etendeka, Deccan, Ethiopian-Yemen traps, Columbia River.

Silicic igneous provinces: Whitsunday (eastern Australia), Chon Aike province (Argentina).

Anorogenic igneous complexes: Damaran province (Namibia); Niger-Nigeria province; many examples in Africa; Gardar province (Greenland), Giles intrusions in central Australia.

Carbonatites, kimberlites, lamproite: numerous fields in southern Africa, Canada, northwest Australia, India, Arabian shield, Brazil.

Examples include the Orange-Limpopo rivers drainage systems related to the Karoo and Etendeka escarpments in southern Africa; in southern Namibia, the Fish River canyon is due to uplift relating to the Tristan da Cunha plume and opening of the South Atlantic. A radial drainage pattern characterises the Mongolian plateau. In Australia, palaeocanyons, up to $250 \mathrm{~km}$ long and $1 \mathrm{~km}$ deep, were incised by regional uplift ascribed to a mantle plume. 


\section{Mantle plumes}

Current ideas on mantle plumes posit that they are "narrow upwelling currents", or "narrow cylindrical conduits" of hot, lowdensity material originating either from the core-mantle boundary (CMB; one-layer mantle model), and/or from the $670 \mathrm{~km}$ discontinuity at the base of the upper mantle (two-layer mantle model) (Davies, 1999; Schubert et al., 2001; Campbell and Davies, 2006). The general consensus is that most large and long-lived plumes originate from the $\mathrm{CMB}$, at the $\mathrm{D}$ " thermal boundary layer, and are caused by heat from the outer core that is focused into a plume, driven upward by buoyancy and in response to sinking of cool lithospheric slabs. The structure of mantle plumes, modelled through numerous laboratory experiments (e.g. Griffiths and Campbell, 1990) and imaged by seismic tomography (e.g. Montelli et al., 2004; Nolet et al., 2006), consists of a tail or stem and a mushroom-shaped head. The plume head is cooler than the tail, because it contains entrained material from the surrounding cooler mantle (Figure1A). Courtillot et al. (2003) identified three types of plumes, namely: 1) primary or deep plumes, originating from the D" layer; 2) secondary plumes, originating from the top of large domes of deep plumes; 3 ) tertiary plumes or Andersonian plumes, originating from near the $670 \mathrm{~km}$ discontinuity and linked to tensile stresses in the lithosphere. The deep plumes are located on antipodal regions, Africa and the central Pacific Ocean, where two massive mantle upwellings are evidenced by high crustal elevation (superswells) and by corresponding regions of low shear wave (Vs) velocity anomalies in the mantle (Gurnis et al., 2000).

The "Andersonian plumes" of Courtillot et al. (2003) represent shallow plumes and may be considered an alternative to the theory of deep mantle plumes. Indeed, a number of researchers do not subscribe to the plume paradigm and maintain that hotspots and flood basalts are not caused by deep plumes. In this respect a recent publication covers a wide range of topics on the subject with the aim of providing alternative explanations (Foulger et al. 2005, and 47 papers therein).

Partial melting in the plume head occurs by adiabatic decompression yielding lower temperature and lower-Mg melts (tholeiitic basalts), whereas melting in the high-temperature tail yields high temperature and high Mg-melts (picrites, komatiites) (Campbell et al., 1989) (Figure 1B). The surface expression of mantle plumes is typically manifested by doming of the crust, reflected as topographic swells of $1000-2000 \mathrm{~km}$ in diameter and from 1000 to $>2000$ m elevations (above sea level; Griffiths and Campbell, 1991), rift basins and intraplate volcanism (Sengör, 2001; Ernst and Buchan, 2003) (Figure 1C). Regions of intraplate anorogenic volcanism are commonly called "hotspots", a loose term that essentially refers to the concept of a stationary heat source in the mantle and the high heat flow that is related to magma advection (Wilson, 1963; Schubert et al., 2001). Geodetic data show that several hotspot regions correlate with rises in the gravitational equipotential surface (geoid high), probably reflecting the buoyancy of heated lithosphere (Perfit and Davidson, 2000). Uplift is followed by subsidence due to loss of buoyancy of the plume head, or removal of magma from the top of the plume, thermal decay, or a combination of all three (Condie, 2001). Subsidence and crustal sagging cause the formation of sedimentary basins, characterized by the deposition of extensive aprons of siliciclastics, carbonates and evaporites, commonly overlain by continental flood basalts and/or transected by related dyke swarms. An example is provided by the Centralian Superbasin in Australia (Walter et al., 1995), where crustal sagging began as a result of a mantle plume activity at about $826 \mathrm{Ma}$ (Zhao et al., 1994), with the deposition of thick successions of marine and fluvial sands. The evolution of this large depositional system continued through to the latest Proterozoic, culminating with the eruption of continental flood basalts from a second plume event at about $510 \mathrm{Ma}$ (Kalkarindji LIP) (Glass and Phillips, 2006). Thus, uplifts related to mantle plumes also record pulses of sedimentary successions that are controlled by eustatic sea level fluctuations, due to an interplay of increased oceanic plateau formation (sea level rise) and supercontinent aggregation (sea level fall) (White and Lovell, 1997).

In addition to normal plume events, there appear to be major pulses of heat transfer in the evolution of the Earth, in which a cluster of plumes impinge on to the base of the lithosphere. These plume events, called superplumes (Larson, 1991; Ernst and Buchan, 2002),

A
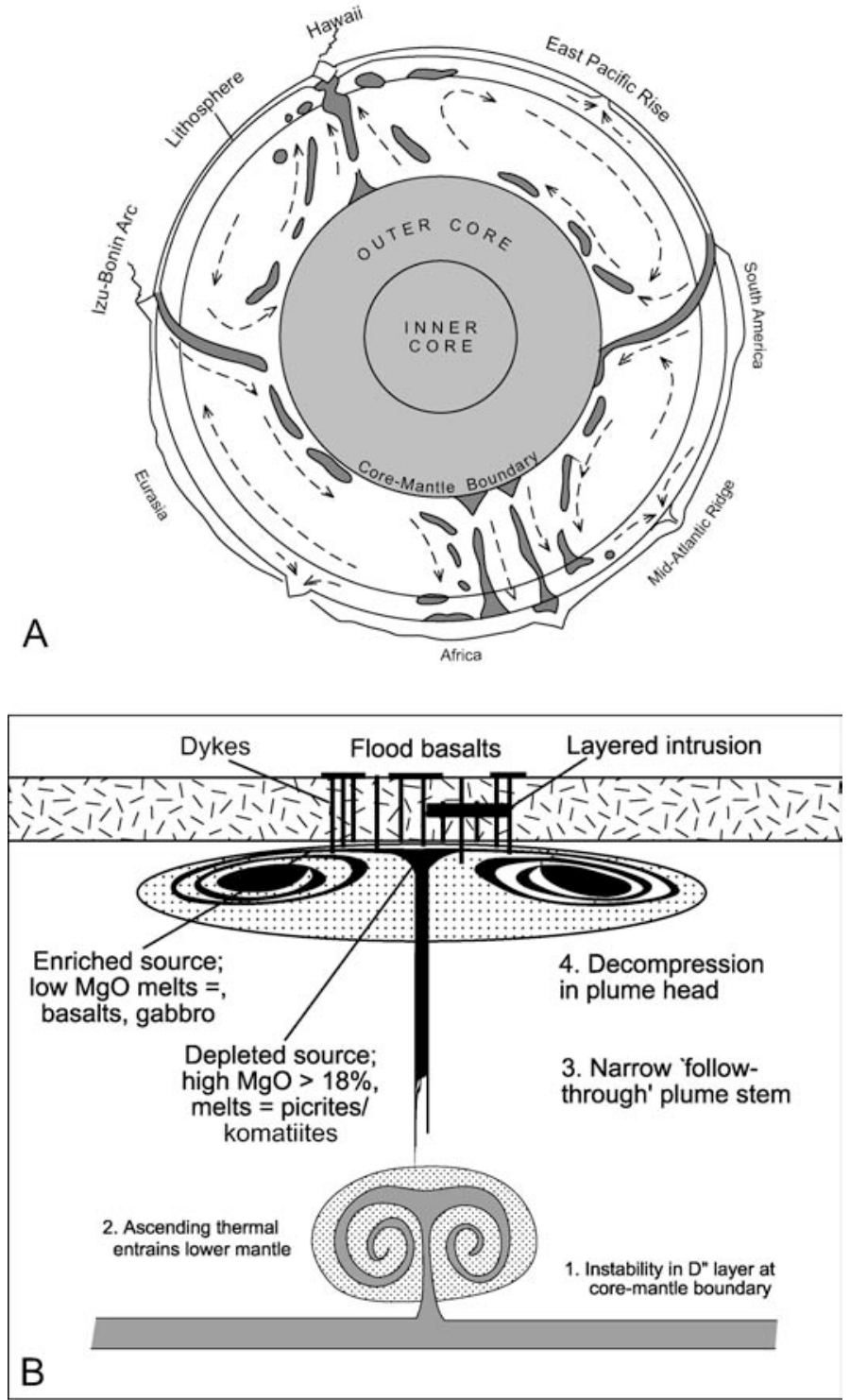

\section{PLUME-LITHOSPHERE INTERACTIONS $2000 \mathrm{~km}$}

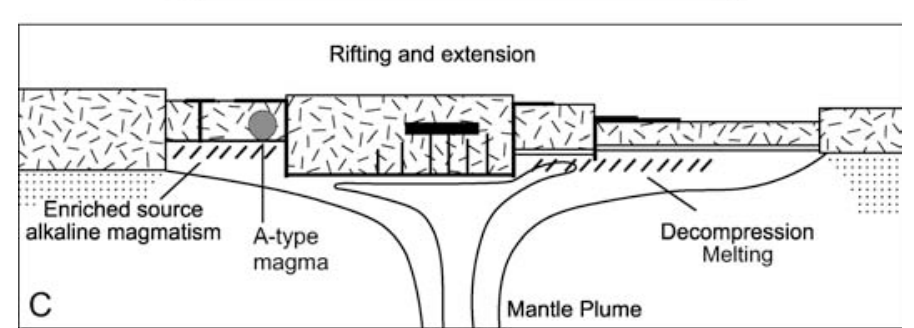

Figure 1 A) Model of mantle convection in the Earth and the rise of mantle plumes; based on Davies and Richard (1992). B) Mantle plume model based on Campbell and Griffiths (1990) and Griffiths and Campbell (1990). C) Uplift and extension result in rifting and decompression melting of the plume head (Saunders et al., 1992), melting of metasomatised subcontinental lithospheric mantle results in alkaline magmatism, whereas melting of lower crust generates Atype magmas. 
have important implications in terms of possible links with supercontinent cycles and time-space distribution of metalliferous deposits (Barley and Groves, 1992; Abbott and Isley, 2002). Superplume events have been recognised in the geological record, which correlate with the growth of continental crust. There are several lines of evidence to indicate that growth of juvenile crust was episodic with major peaks recorded at 2.7-2.6 Ga, 1.9-1.8 Ga, 0.5-0.2 Ga, while peak mantle plume events are recorded at $3.0 \mathrm{Ga}, 2.8 \mathrm{Ga}, 2.5$ Ga, 1.8-1.7 Ga, 1.1-1.3 Ga, 0.4 Ga, 0.25-0.1 Ga (Condie, 2004; Groves et al., 2005).

The eruption and intrusion of great volumes of mafic and ultramafic melts is attributed to the rise and impingement of mantle plumes on continental and oceanic lithospheric plates. These largescale emplacements of mafic rocks are termed Large Igneous Provinces (LIPs; Coffin and Eldhom, 1992). The eruptions of these mafic melts form vast fields of lava flows and associated igneous complexes, up to $7 \times 10^{6} \mathrm{~km}^{2}$ in areal extent (e. g. Central Atlantic province; Marzoli et al., 1999; Siberian flood basalt province; Nikishin et al., 2002), or lines of oceanic islands, such as the EmperorHawaian chain, thousands of kilometres long. In the ocean these vast lava fields are known as oceanic plateaux, such as the Ontong JavaManihiki-Hikurangi and Kerguelen plateaux (Taylor, 2006). Plumes may also interact with mid-ocean ridges forming large islands, such as Iceland. There is geophysical, geological and bathymetric evidence for the presence of voluminous mafic extrusive and intrusive complexes along the passive, trailing edges of continents that have been rifted and separated by sea floor spreading. These complexes exhibit prominent seismic seaward-dipping reflectors, or seawarddipping layers at the flanks of, and parallel to the continental slope. Typically, they are underlain by high-velocity bodies $\left(7.2-7.5 \mathrm{~km} \mathrm{~s}^{-1}\right)$, like those observed beneath oceanic plateaux. Reflectors on the southeastern and eastern Greenland coast, correlate with on-shore Tertiary flood basalts, together forming part of the North Atlantic Igneous Province (Klausen and Larsen, 2002).

In addition, to mafic LIPs, the emplacement of silicic large igneous provinces (SLIP) is commonly overlooked and only comparatively recently recognised (Bryan et al., 2002). SLIPs form volcano-plutonic belts that can be 1000s of km long, associated with continental rifts and volcanic rifted margins. Examples of SLIPs include the $\sim 130-95 \mathrm{Ma}$ Whitsunday igneous province in eastern Australia and the $\sim 188-153$ Ma Chon Aike province in South America and Antarctica. SLIPs are economically important because they can be associated with hydrothermal mineralisation, as discussed by Bryan in this issue.

The emplacement of LIPs has also been correlated with climate change and mass extinctions (e. g. Wignall, 2001). This correlation is possibly due to massive emission of $\mathrm{CO}_{2}$ from volcanic eruptions and/or the breakdown of methane clathrates (Jahren, 2002).

Where mantle plumes impinge onto subcontinental lithosphere, rifting may occur and may be accompanied by the eruption of continental flood basalts (CFB), exemplified by the well-studied ParanáEtendeka, Karoo-Ferrar, Siberian and Deccan provinces. It is important to remember that the location of lava flows, sill complexes and layered intrusions are not necessarily indicative of a plume centre, because mafic melts can be transported for great distances from the plume centre or head. An example is provided by the Ferrar igneous province of Antarctica, which is cogenetic with the Karoo province of southern Africa. The emplacement of the Ferrar province was controlled by a huge rift system in the early Jurassic, in which magma dispersal, from a single batch, took place along $3000 \mathrm{~km}$ at mid-upper crustal levels (Elliot et al., 1999).

Ideally, a plume centre could be identified by the focal point of converging giant dyke swarms, such as the great Mackenzie swarm in Canada (Ernst and Buchan, 2001; Ernst et al., 1995), or converging rift systems (triple junction). The $1.26 \mathrm{Ga}$ Mackenzie dyke swarm is the largest on Earth $(2400 \mathrm{~km}$ long and a maximum width of $1800 \mathrm{~km}$ ) and is the best illustration of the spatial and genetic link with layered intrusions and flood basalts. The Mackenzie swarm fans out of a focal point in northwestern Canada, where it is suggested that a hotspot and underlying mantle plume existed. This is sup- ported by the presence in the area of regional gravity highs, which may be caused by shallow mafic-ultramafic intrusions (Baragar et al., 1996). The swarm is spatially associated and coeval with the Muskox layered intrusion and the Coppermine River flood basalts.

The classic scheme of plume-generated three-arm rifting proposed by Burke and Dewey (1973) remains a valid concept. Indeed, many rift systems are associated with crustal swells, as exemplified by the North Sea Basin and the East African rifts. The timing of extension, igneous activity, uplift, and subsidence, determines the nature of the rifting process, which can be active or passive. Active rifting is believed to be a direct consequence of the impact of mantle plumes onto the lithosphere and is preceded by uplift of the crust and thinning of the lithosphere (e.g. East African rifts); the initial stages of active rifting are typically accompanied by alkaline bimodal (mafic-felsic, both extrusive and intrusive) magmatism. Passive rifting, on the other hand is linked to lithospheric stresses, related to plate boundary forces and may be collision related (e.g. impactogens, such as the Rhine rift system and perhaps the Baikal rift; Sengör et al., 1978; Mats, 1993). The concept of active and passive rifting is somewhat contentious and a case for interactions of rifting processes associated with both plate boundary forces and mantle plumes has been made for the Late Permian-Triassic rift basins, located between the East European and Siberian Cratons, with which the great Siberian traps (or Tunguska flood basalts) are related (Nikishin et al., 2002). Reviews of active and passive rifting processes are given in Ziegler and Cloetingh (2004).

The best modern example of a triple junction is the Afar triangle in the horn of Africa (Mohr, 1978; Yirgu et al., 2006). The Afar is a depression at the triple junction defined by the Red Sea, the Gulf of Aden and the Ethiopian part of the 5000 km-long East African Rift System (EARS). The Afar triangle is the triple junction that marks the transition between the continental and oceanic rifts (Red Sea and the Gulf of Aden) of the EARS (Figure 2). The Afar region is characterized by fissure-fed tholeiitic volcanism, hot springs and playa lakes with thick evaporite deposits (Barberi and Varet, 1978), and as such provide all the necessary ingredients for a wide range of magmatic-hydrothermal and hydrothermal ore systems, as discussed below. The Afar, together with the Ethiopian and East African

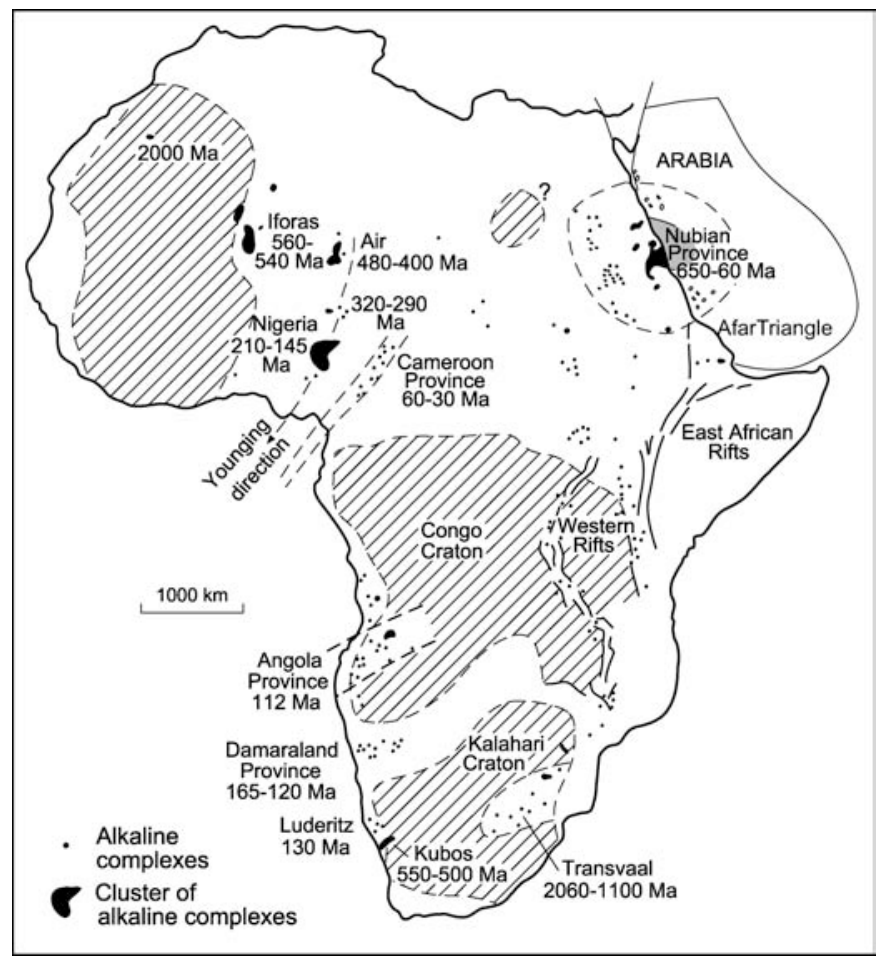

Figure 2 Anorogenic magmatism: distribution of alkaline complexes in Africa, showing spatial relationship to crustal fractures related to plume events (Pirajno, 2000 and references therein). 
plateaux, is the general area, where a mantle plume is impinging beneath the continental lithosphere. This is the conclusion reached by Ebinger and Sleep (1998), who on the basis of gravity data and geochemistry of the volcanic products, numerically modelled the dynamics of the Afar mantle plume. Rogers et al. (2000), on the basis of $\mathrm{Sr}, \mathrm{Nd}$, and $\mathrm{Pb}$ isotope systematics and geochemical data, suggested that the EARS is underlain by two mantle plumes, one beneath the Kenya rift and the other beneath the Ethiopian rift and Afar region. An important concept proposed by Ebinger and Sleep (1998) is that the effects of the Afar-east African plume might extend along the EARS, to the south, offshore to the Comoros islands, and to the west along the Darfur swell and the Ngaoundere rift (Cameroon Line). In their model, the authors suggested that the plume head flattens beneath the lithosphere, and flows laterally in zones where the lithosphere is thinner. In this way the behaviour of the plume, in terms of melting, is controlled by pre-existing variations in the thickness of the lithosphere, such as those of the west African Mesozoic rift zones and along the passive margins of Africa and Arabia.

Anorogenic alkaline magmatism commonly accompanies both mafic-ultramafic dominated and silicic LIPs. Typically associated with intracontinental rift systems, anorogenic magmatism is best exemplified in the African continent where alkaline complexes are widespread and locally well-studied (Kinnaird and Bowden, 1987) and their relationship to plume magmatism is perhaps more obvious. The African alkaline magmatism spans a range of ages, from the 2050 Ma Palabora intrusion, through the 1350 Ma Pilanesberg, the 500 Ma Kuboos-Bremem province (South Africa), the Mesozoic and Tertiary volcano-plutonic complexes in Nigeria, Angola and Namibia, to the modern volcanic centres along the East African Rift System (Figure 2).

Plumes may also interact with passive continental margins, forming thick piles of mafic rocks, as in the North Atlantic volcanic margin, which links the southeast coast of Greenland with Iceland (Eldhom and Grue, 1994). Mantle plume-island arc interactions have been postulated for the Archaean Abitibi-Wawa greenstone belts in the Superior Province. In addition, the lithological associations of greenstone belts of the Superior province suggest that they represent accreted tectonic domains that include plume-generated oceanic plateaux and island arc systems (Wyman et al. 2002). These tectonic interpretations that involve mantle plumes have important implications for orogenic precious metal mineralising systems (Groves et al. 2005).

\section{Possible links with meteorite impacts?}

Some authors have proposed that meteorite impacts can induce mantle plumes, decompression melting and the inception of large igneous provinces. There is circumstantial evidence, within the limits of isotopic age dating errors, of a possible link between biological mass extinctions, large meteorite impacts and flood volcanism (Becker, 2002). A correlation between major bolide impacts and mantle plume breakouts is advocated by Abbott and Isley (2002). These authors have examined the timing of known major impacts for the last $3800 \mathrm{Ma}$ of Earth's history and found that a correlation exists with hotspot volcanism, suggesting that the upwelling of mantle diapirs may have something to do with large meteorite impacts. Support for this hypothesis comes from computer simulations by Jones et al. (2002), in which they show that a large impact can cause decompression melting and the rise of a mantle plume. These views, however, are controversial because of the poor age constraints on actual dated impacts and the error limits of isotopic ages of mantle plume proxies, such as large igneous provinces and mafic-ultramafic layered intrusions. Nevertheless, the apparent coincidence of impacts, mass extinctions and volcanism, although poorly-defined statistically and chronologically, is striking and provides food for thought (White and Saunders, 2005).

\section{Ore systems}

A great variety of ore systems, magmatic and hydrothermal, form in mantle plume-related tectono-magmatic settings. As previously mentioned, we can consider these ore systems in terms of two endmembers: 1) magma-associated and; 2) hydrothermal systems powered by the thermal energy released by the cooling of anorogenic magmas in the crust. Two specific ore systems are age-dependant in that they are only found in Archaean and in Palaeo-Mesoproterozoic rocks, they are komatiite-hosted $\mathrm{Ni}-\mathrm{Cu}$ deposits and iron-formations. Each are discussed within their appropriate category, magmaassociated and hydrothermal, respectively.

\section{Magma-associated ore systems}

An overview of magma-associated ore systems that can be linked to mantle plume activity is shown in Table 2. The closest link with mantle plumes is probably represented by the mafic-ultramafic layered intrusions, dykes and associated LIPs. Erosion of continental flood basalts exposes feeder dykes, sill complexes and magma chambers (layered intrusions). Mafic dyke swarms, sill complexes and layered intrusions therefore represent the remnants of large igneous provinces and can, in the right conditions, host magmatic ore deposits.

Anorogenic magmatism is associated, in space and time, with extensional tectonics, hotspots and intracontinental rifts. Intracontinental alkaline magmatism usually occurs during the early phases of rifting events, in which direct links are assumed with melt generation by mantle plume upwellings beneath thinned lithosphere. Anorogenic alkaline complexes and carbonatites are present in many LIPs (e.g. Deccan, Siberian traps, Paraná -Etendeka, Keeweenawan).

\section{Mafic-ultramafic systems}

Orthomagmatic ore deposits are typically hosted by maficultramafic layered intrusions, dykes, sill complexes, continental flood basalts, and Archaean komatiite fields. Lambert et al. (1998) proposed a three-fold classification of magmatic ore deposits: 1) $\mathrm{Cu}-\mathrm{Ni}$-PGE-rich sulphides, chromite and Fe-Ti-V oxides, hosted in mafic-ultramafic layered intrusions (e.g. Bushveld Complex, Great Dyke in southern Africa); 2) $\mathrm{Cu}-\mathrm{Ni}$ sulphides associated with basaltic and gabbroic rocks (e.g. Duluth in the USA, Noril'sk-Talnakh in Russia, Jinchuan in China); 3) Archaean komatiite Ni sulphides (e.g. Kambalda in Western Australia). In terms of metal production, magmatic sulphide deposits can be divided into (Li et al., 2001): 1) Ni-Cu deposits with PGE as by-products; 2) PGE deposits with $\mathrm{Ni}-\mathrm{Cu}$ as by products (Figure 3 ). Examples of the former are the Kambalda deposit in Western Australia, Jinchuan in China, Noril'sk in Russia, Voisey's Bay in Canada. Important deposits of the second type are the UG-2 chromitite and Merensky Reef of the Bushveld Complex (South Africa), the Great Dyke (Zimbabwe) and the J-M Reef of the Stillwater Complex (USA). Abbott and Isley (2002) suggested that layered intrusions formed by deep-mantle plume events contain high level of PGE and $\mathrm{Cr}$, because these plumes are associated with high degrees of melting in the mantle and therefore higher concentrations of compatible elements such as $\mathrm{Pt}$ and $\mathrm{Cr}$. It has also been suggested that "second stage" melts of mantle material can be PGE-enriched as a consequence of prior melt extraction from an S-saturated mantle source (Hamlyn and Keays, 1986).

Magmatic segregations of $\mathrm{Cu}-\mathrm{Ni}$ sulphides and PGE are due to liquid immiscibility between a silicate magma and a sulphide liquid, probably facilitated by introduction of crustal sulphur into a silicate melt that was originally sulphur-undersaturated. The immiscible sulphide liquid efficiently scavenges metals such as PGE, Ni and $\mathrm{Cu}$. Iron-Ti-V oxides tend to appear in the same layered intrusions, but at different statigraphic levels in layers of different composi- 


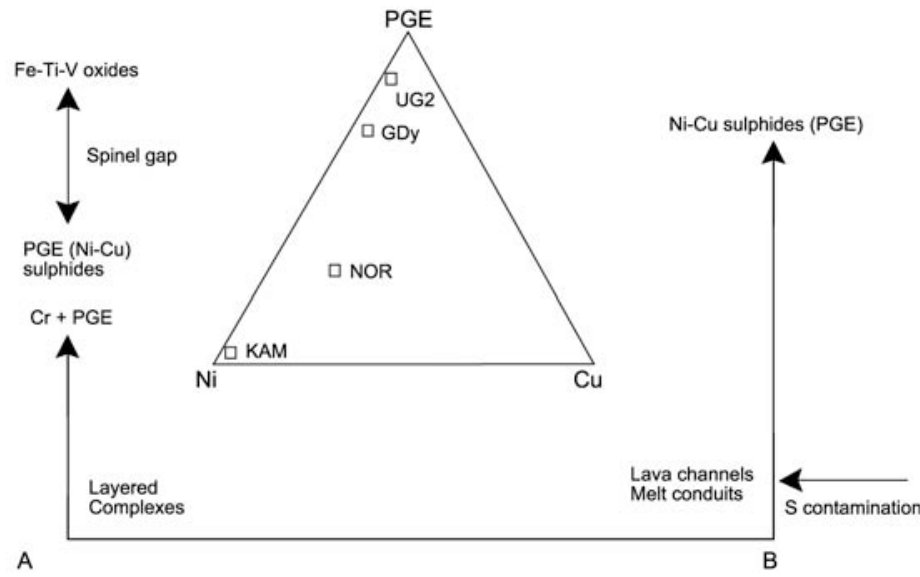

Figure 3 Schematic illustration showing the two main paths of $\mathrm{Ni}-\mathrm{Cu}$ and PGE magmatic ore systems in mafic-ultramafic magmas. Path A relates primarily to layered intrusions, with $P G E$ and lesser $\mathrm{Ni}-\mathrm{Cu}$ sulphides, $\mathrm{Cr}+\mathrm{PGE}$ and $\mathrm{Fe}-\mathrm{Ti}-\mathrm{V}$ oxides being segregated directly from the melts. Path $B$ is where crustal contamination and $S$ addition occur and play a critical role in the formation of magmatic sulphide mineralisation. The triangular diagram qualitatively displays the position of some of the worldclass magmatic deposits: KAM Kambalda, NOR Noril'sk, GDy Great Dyke of Zimbabwe, UG2 platiniferous chromitite of the Bushveld Complex. More details in the text. After Pirajno (2004a).

tion. Thus, a common theme in layered intrusions, is that $\mathrm{Cr}$ and $\mathrm{PGE} \pm \mathrm{Ni}-\mathrm{Cu}$ ores are associated with magmas having high $\mathrm{Mg} / \mathrm{Fe}$, poor $\mathrm{Ca}$ and alkali contents; whereas $\mathrm{Fe}-\mathrm{Ti}-\mathrm{V}$ oxides are associated with magmas that are richer in $\mathrm{Fe}$ and alkali+Ca. Consequently, sulphide and $\mathrm{Cr}$ mineralisation is commonly confined to the ultramafic layers at the base of the layered sequence, whereas Fe-Ti-V mineralisation is localised within mafic rocks at the top of the sequence.

Critical to these different deposits $(\mathrm{Ni}-\mathrm{Cu} \pm \mathrm{PGE}$ and $\mathrm{PGE} \pm \mathrm{Ni}-$ $\mathrm{Cu}$ ) is the style of sulphide accumulation (Figure 4). In large layered intrusions sulphide droplets are segregated from the melt and settle on the floor of the magma chamber (Figure 4A). In the case of $\mathrm{Ni}-\mathrm{Cu} \pm$ PGE (e. g. Noril'sk, Voisey's Bay) sulphide deposition is controlled by fluid dynamics in a magma conduit system (Naldrett, 1997) (Figure 4B). Addition of sulphur to a metal-rich melt is a necessary prerequisite in order to induce $\mathrm{S}$ saturation and the subsequent segregation of sulphides. The sulphide-rich melts are mechanically transported along conduits towards the surface (Figure 4B), where they may passively accumulate, because of loss of velocity, at bends or structural traps, while the residual metaldepleted melt continues its upward ascent to erupt at the surface or to be emplaced as metal-depleted mafic sills (Naldrett, 1997). In the case of the Noril'sk deposits, the flow of large volumes of magma through overlying S-rich crustal or sedimentary rocks, such as evaporites and coal measures, would have caused the ingestion of S-rich rocks by the melts, thereby promoting sulphide saturation and precipitation (Naldrett, 1997). However, the role of contamination by high-Si and low-S crustal materials at deep levels is increasingly being considered as an alternative. For example, Ripley et al. (2002) suggested the possibility of fractional melting and total fusion of pelitic and graphitic gneiss rocks as a viable mechanism for the addition of $\mathrm{S}$ and $\mathrm{C}$ to the magma to cause the precipitation of magmatic sulphides.

\section{Archaean komatiites}

Komatiite is defined as an ultramafic volcanic rock with $>18$ wt $\% \mathrm{MgO}$, on an anhydrous basis with $\mathrm{TiO}_{2}<1 \%$ and $\mathrm{Na}_{2} \mathrm{O}+\mathrm{K}_{2} \mathrm{O}$ $<1 \%$ (Le Maitre, 2002). Komatiites are generally confined to the Archaean and Palaeoproterozoic because of higher mantle potential
A MAGMATIC CUMULATES

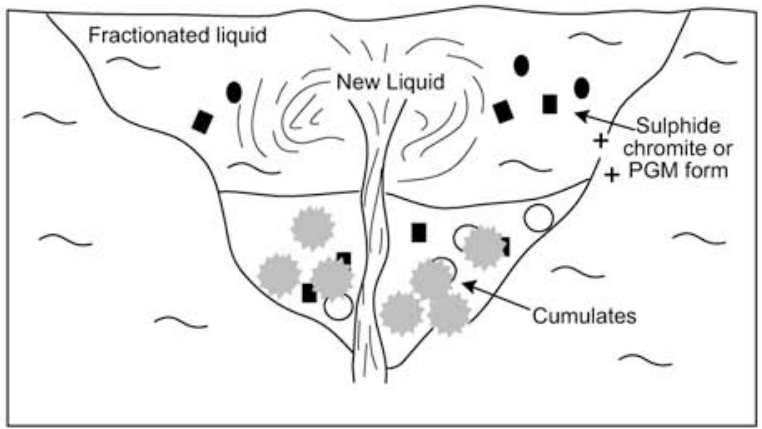

B MELT CONDUIT

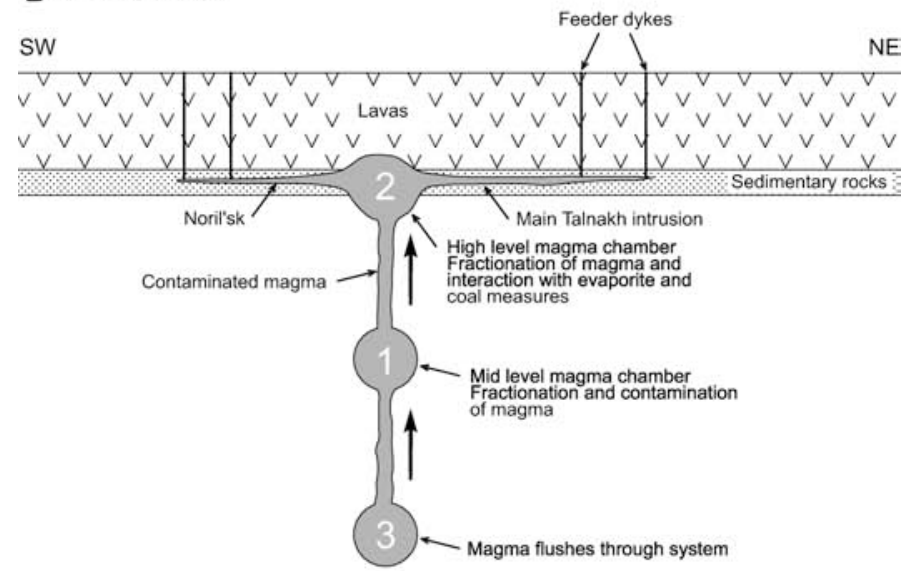

C LAVA CHANNEL

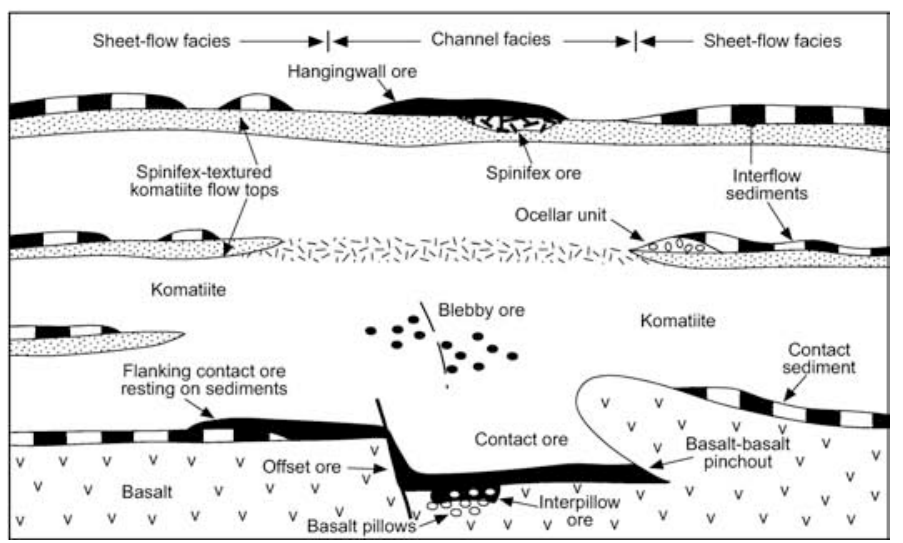

Figure 4 Ore genesis models for magmatic sulphide ores. A) sulphide segregations in a layered intrusion (Barnes and Maier, 1999); B) sulphides are precipitated in a conduit system, by repeated pulses of magmas (Naldrett, 1997); C) schematic section of a lava channel (not to scale) in which komatiite-hosted $\mathrm{Ni}$-Cu sulphides are precipitated (Hill et al. 1990).

temperature $\left(\sim 1600{ }^{\circ} \mathrm{C}\right)$ compared to present day $\sim 1380{ }^{\circ} \mathrm{C}$ (Abbott et al., 1994). Komatiite lavas are important hosts of $\mathrm{Fe}-\mathrm{Ni}-\mathrm{Cu}$ sulphide mineralisation in Archaean greenstone belts in Australia, Canada, Zimbabwe and Brasil. Komatiite-hosted Ni-Cu $( \pm$ PGE) deposits have been divided into two types (Lesher and Keays, 2002). Type 1 are stratiform accumulation of $\mathrm{Fe}-\mathrm{Ni}-\mathrm{Cu}$ sulphides in embayments or troughs at the base of komatiite lava flows (e.g. Kambalda, Western Australia) (Figure 4C). Type 2 are stratabound disseminated sulphides hosted in thick dunitic cumulate rocks (e. g. Mt Keith, Western Australia). Details of the komatiite-hosted $\mathrm{Ni}-\mathrm{Cu}$ $( \pm$ PGE) mineralisation can be found in Lesher and Keays (2002). 
It has been suggested that the Archaean greenstone komatiitetholeiite sequences are products of mantle plumes (e.g. Tomlinson et al. 1998), and furthermore that these sequences may be the fragments of plume-related oceanic plateaux, by analogy with a rare Phanerozoic komatiite on Gorgona Island (Storey et al., 1991). The Archaean Abitibi-Wawa granite-greenstone belt (Superior Province, Canada) is a complex collage of accreted oceanic plateaux and island arcs that interacted with a flat-subduction event and the involvement of a mantle plume, which coupled with the entire subduction-accretion system (Wyman et al., 2002). The impingement of a mantle plume beneath an accretion-subduction system in the Archaean is reminiscent of the Great Basin geodynamics (referred to below), where the tectono-magmatic history of the region involved shallow subduction and later underplating by a mantle plume (Yellowstone hotspot), with uplift (the Basin-and-Range plateau has an average elevation of $1500 \mathrm{~m}$ a. s. 1.), rifting and anorogenic magmatism (Ilchik and Barton, 1997; Oppliger et al., 1997)..

Campbell and Hill (1988) and Hill et al. (1991) proposed that the Late Archaean greenstone sequences of the Eastern Goldfields of the Yilgarn Craton (Western Australia), which contain abundant komatiite rocks, are the result of high degrees of melting in mantle plume tails (Figure 1B). Seen in this light, the komatiites of the Eastern Goldfields (Yilgarn Craton, Western Australia) can be considered as an Archaean flood basalt province (Hill et al., 1991). However, there is no consensus regarding the origin of komatiites. In contrast to the mantle plume hypothesis other workers suggested that the Archaean greenstone belts and komatiites were formed in subduction-related oceanic island arcs that were later accreted by plate convergence (e. g. de Wit, 1998). Thus, the origin of komatiites remains a debated topic. For details of komatiite magmatism and associated Ni sulphide mineralisation the reader is referred to Arndt (1994) and Barnes et al. (1999).

\section{Ore deposits associated with anorogenic magmatism}

The nature of anorogenic magmatism is complex and varied, but for the purpose of this contribution, I consider three groups: 1) intracontinental A-type magma complexes, 2) anorthosite-gabbrotroctolite (or massif-type) complexes, 3) kimberlites, lamproites and carbonatites. Anorogenic magmas host or are associated with a great variety of ore deposits, which include both magmatic and magmatichydrothermal (Table 2). Anorogenic magmas are enriched in incompatible elements (e. g. Ti, P, Y, Nb, K, Th, U, F, Ba, REE) and produce peraluminous and peralkaline granitoids, which commonly contain greisen or late-magmatic sub-solidus $\mathrm{Sn}, \mathrm{W}, \mathrm{Zn}, \mathrm{Cu}, \mathrm{U}, \mathrm{Nb}$ mineralisation (Pirajno, 1992).

Ore deposits of A-type magmas also include the economically important $\mathrm{Fe}$ oxide-Cu-Au-U-REE class (IOCG; Table 2). Typically, IOCG hydrothermal systems form in shallow crustal environments $(4-6 \mathrm{~km})$ and are the expression of volatile-rich, alkaline magmas (Hitzman et al., 1992). Their global occurrence appears to be linked to planetary-scale rifting events and the assembly and breakup of supercontinents, such as Rodinia (Barley and Groves, 1992; Groves et al., 2005). The IOCG style mineral systems (Williams et al., 2005) are represented by giant ore deposits that intrude Olympic Dam and Ernest Henry in Australia, Carajas in Brazil, Candelaria in Chile, Palabora in South Africa. The general theme of the IOCG deposits is the enrichment in $\mathrm{Fe}, \mathrm{Cu}, \mathrm{Au}, \mathrm{P}, \mathrm{F}$, REE, U, and the widespread alkali ( $\mathrm{Na}-\mathrm{Ca}$ and $\mathrm{K}$ ) metasomatism in both host rocks and at district scale.

Massif-type gabbro-anorthosite-troctolite intrusive complexes which appear to be related to rift settings and/or terrane boundaries, mainly host magmatic ore deposits. Massif-type anorthosite magmatism is widespread in the $1.5-1.3 \mathrm{Ga}$ time span, forming a belt 5000 $\mathrm{km}$ long and $1000 \mathrm{~km}$ wide that extends across the Laurentian shield, from present-day California through to Scandinavia (Windley, 1995). The origin of these anorthosite intrusions, many of which also contain important resources of $\mathrm{Fe}-\mathrm{Ti}-\mathrm{V}$ and $\mathrm{Ni}-\mathrm{Cu}-\mathrm{Co}$, is not clearly understood. Windley (1995, p. 264) proposed a model that attempts to explain this type of anorogenic magmatism. He suggested that supercontinent breakup is initiated as a result of extension above a mantle plume head, with the production of lower crustal melts, including anorthosites.

Iron-Ti-V ores (ilmenite-magnetite) form by magmatic segregation, perhaps triggered by episodic increases in $\mathrm{f}_{\mathrm{O} 2}$, resulting in the development of a Fe-Ti oxide liquid that becomes trapped in the interstices of plagioclase and clinopyroxene crystals, a mechanism not dissimilar to that responsible for the formation of chromitite layers. In the southern hemisphere, one of the world's largest massiftype anorthosite complex is the north-trending, 300-km long, ca 2.0 Ga Kunene Intrusive Complex, exposed across the Kunene River, marking the border between Angola and Namibia. The Complex hosts large bodies of massive titaniferous magnetite and disseminated ilmenite as well as economically important sodalite (Schneider, 1992). Fe-Ti-V deposits associated with magnetite seams are present in the Giles intrusions in the Musgrave Complex of central Australia (Pirajno et al., 2006). The Giles mafic-ultramafic intrusions are part of the $1076 \mathrm{Ma}$ Warakurna LIP (Wingate et al. 2004), which is inferred to be related to a mantle plume (Morris and Pirajno, 2005). The Warakurna LIP provides an interesting example of a magmatic event which encompasses dyke swarms, mafic sill complexes, bimodal volcanism, A-type granitic intrusions as well as the extensive Giles mafic-ultramafic intrusions (Pirajno et al. 2006). The mineral systems potential of the Warakurna LIP can be therefore be considered in terms of primary magmatic ores in mafic-ultramafic layered intrusions, sill complexes (Noril'sk type and/or Voisey's Bay), anorogenic complexes and hydrothermal deposits (Figure 5). The Giles intrusions are associated in space and time with bimodal volcanic rocks of the Bentley Supergroup and various types of 1090$1060 \mathrm{Ma}$ A-type and rapakivi granitic rocks.

The unusual and enigmatic Okiep copper district of Namaqualand (South Africa) is possibly an anorthosite magmatic system, within a mantle-plume generated mid-Proterozoic rift system (Namaqua Metamorphic Complex) (Willner et al., 1990). The 1060 Ma Koperberg Suite includes anorthosites, diorites and pyroxenites, forming about 1700 pipes and dyke bodies (known as basic bodies) in granulite facies gneisses and granitoids of the Okiep Group. The Okiep copper ores contain abundant bornite, which is not considered typical of magmatic sulphides (Maier, 2000). The origin of the sulphide ores of the Okiep basic bodies still defies explanation, but it is possible that original primary magmatic sulphides were modified, perhaps as a result of high-temperature metamorphism (Maier, 2000).

Mesoproterozoic (ca $1.3 \mathrm{Ga}$ ) anorthosite-leuconorite-troctolite intrusions are present in Labrador (Canada). In Eastern Labrador, these intrusions are part of a larger igneous body of batholitic dimensions, known as the Nain Plutonic Suite, which straddles the Abloviak Shear Zone and intruded at approximately 1.33-1.29 Ga. The Nain Suite includes granites, anorthosite, diorite and troctolite rocks. Members of the Suite contain the Voisey's Bay Ni-Cu-Co deposit, hosted in troctolite rocks that are interpreted to be the feeder to overlying intrusions (Naldrett, 1997). Recent research, based on $\mathrm{S}, \mathrm{C}, \mathrm{O}$ isotopic data and $\mathrm{Se} / \mathrm{S}$ ratios, supports the idea that a combination of S-rich pelitic country rock and melting of xenoliths was a strong contaminant to the basaltic magma that gave rise to the Voisey's Bay intrusion (Ripley et al., 2002). The above-mentioned Giles mafic-ultramafic intrusions in central Australia also contain a Voisey Bay's style deposit, the gabbro-norite hosted Nebo-Babel Ni$\mathrm{Cu}$ sulphides, formed during a series of multiple magma pulses within a chonolitic intrusion (Seat et al., in press). The Nebo-Babel magmatic deposit is the largest $\mathrm{Ni}-\mathrm{Cu}$ sulphide discovery for the last 10 years (Seat et al., in press).

Included in anorogenic magmatism are kimberlites, lamproites and carbonatites. These rocks are known to have isotopic signatures $(\mathrm{He}, \mathrm{Os}, \mathrm{Sr}, \mathrm{Nd}, \mathrm{Pb}, \mathrm{O}$ ) similar to ocean island basalts, and as such are considered as part of plume magmatism (Bell, 2001). They may represent distal expressions resulting from the channelling of plume material along pre-existing lithopheric breaks, small degrees of melting of enriched/metasomatised lithosphere and/or crustal melts. Ebinger and Sleep (1998), suggested that a mantle plume may focus 
Table 2 Magma-associated ore systems related to mantle plumes.

\begin{tabular}{|c|c|}
\hline ORE SYSTEM & MAIN GEOLOGICAL FEATURES \\
\hline Layered mafic-ultramafic complexes $\mathrm{Cr}, \mathrm{PGE}, \mathrm{V}, \mathrm{Fe}, \mathrm{Ti},(\mathrm{Cu}, \mathrm{Ni})$ & $\begin{array}{l}\text { - The main feature is the large size of the bodies, and the nature of } \\
\text { layering coupled with remarkable lateral extent. Representing } \\
\text { multiple influxes of melts from the mantle. The mafic-ultramafic } \\
\text { rocks host oxides and sulphides mineralisation and generally } \\
\text { have high initial Sr ratios (crustal contamination) } \\
\text { - In the Great Dyke chromite occurs in seams and disseminations } \\
\text { in olivine-bearing rock. In the Bushveld Complex Cr is concen- } \\
\text { trated in lower ultramafic parts of the complex (lower Critical } \\
\text { Zone). Chromitite seams have great lateral extent. } \\
\text { - Platinum Group Metals occur in the Merensky Reef and similar } \\
\text { layers } \pm 2000 \text { m above the base of the Bushveld Complex; in sim- } \\
\text { ilar bodies and levels in the Stillwater Complex, and the Great } \\
\text { Dyke. } \\
\text { Titaniferous magnetite } \pm \text { vanadium ores in the Bushveld Complex } \\
\text { are within the upper zone, and the top of the main zone gabbro- } \\
\text { norites. Upper zone has cumulative magnetite disseminated in } \\
\text { gabbros and as thick magnetite layers. }\end{array}$ \\
\hline
\end{tabular}

Flood basalts and sill complexes: $\mathrm{Ni}-\mathrm{Cu}(\mathrm{PGE})$

Anorogenic granites (A-type) Sn, Nb, Ta, W, U, Th, F, Be, Zn, Cu Rapakivi granites.
- Related to mafic-ultramafic feeders/conduits located along zones of crustal weakness (e. g. Noril'sk-Talnakh, Siberia).

- Disseminated to massive Ni-Cu sulphides along the basal contact of sill-like intrusions, or Archaean komatiite lava channels (e.g. Kambalda, Western Australia). S-rich sedimentary rocks form substrate of lava channels.

- Sulphides may also occur as disseminations and veins in footwall rocks.

- Granites emplaced in stable intracratonic environments, commonly as ring complexes, and may form extensive "linear" arrays.

- Some important rock types are paralkaline albite-riebeckite granites. Sn is associated with less alkaline biotite granites.

- In Nigeria, Sn, Ta occurs as disseminations, within greisen zones and quartz veins with base metal sulphides. Commonly concentrated along horizontal roof sections of biotite granite.

- In the Bushveld Complex, Sn, F occurs in pipes, sheet-like disseminations in coarse-grained porphyry granites, or as fissure veins, breccia zones or replacement bodies in the granites or their volcanic and sedimentary roof zones. Associated minerals include tourmaline, sericite, quartz, fluorite, and chlorite.

- Rapakivi in Scandinavia. Enrichment in Sn and/or Be, W, Zn, $\mathrm{Cu}$. Mineralisation is related to the youngest phases, and is especially enriched in the apical parts or at contacts. Mineralisation occurs as disseminations, in pegmatite veins, greisens, and quartz veins and contact skarns.

Anorogenic granitoids and Fe oxide-Cu-Au (IOCG)

- A class that includes a wide range of ore deposit styles, such as Olympic Dam, Ernest Henry (Australia), Bayan Obo (China), Kiruna (Sweden). Vergenoeg, ?Palabora (South Africa); ores are associated with breccia pipes or bodies; alkali metasomatism and hematitic alteration at the regional scale. Granitoids have high K, REE, Zr, Y, F, U, Th.

Massif-type anorthosite: Fe-Ti-V; troctolite-anorthosite $\mathrm{Cu}-\mathrm{Ni}-\mathrm{Co}$ )

- Massif type intrusives, limited time control (1.5-1.0 Ga). Mostly occur in two linear belts (one in the Southern Hemisphere and the other extending across North America through Scandinavia to Russia.

- Commonly intruded into high grade regionally metamorphosed rocks. Bodies are sheet-like. Usually plagioclase-rich $(90 \%$ plag); deep level emplacement, whereas associated shallow level gabbroic, norite, and troctolitic anorthosites have 78-90\% plagioclase. Giles mafic intrusions in central Australia may belong this category.

- $\mathrm{Cu}-\mathrm{Ni}$-Co in troctolite-anorthosite complexes (e.g. Voisey'Bay, Canada, ?Nebo-Babel, Western Australia).

- Disseminated Fe and Fe-Ti oxide ores, with occasional lenses or irregular bodies of massive ilmenite. Ti-magnetite commonly enriched in vanadium in gabbroic anorthosite, or noritic gabbro, ilmenite-hematite in cores of anorthosite bodies. 


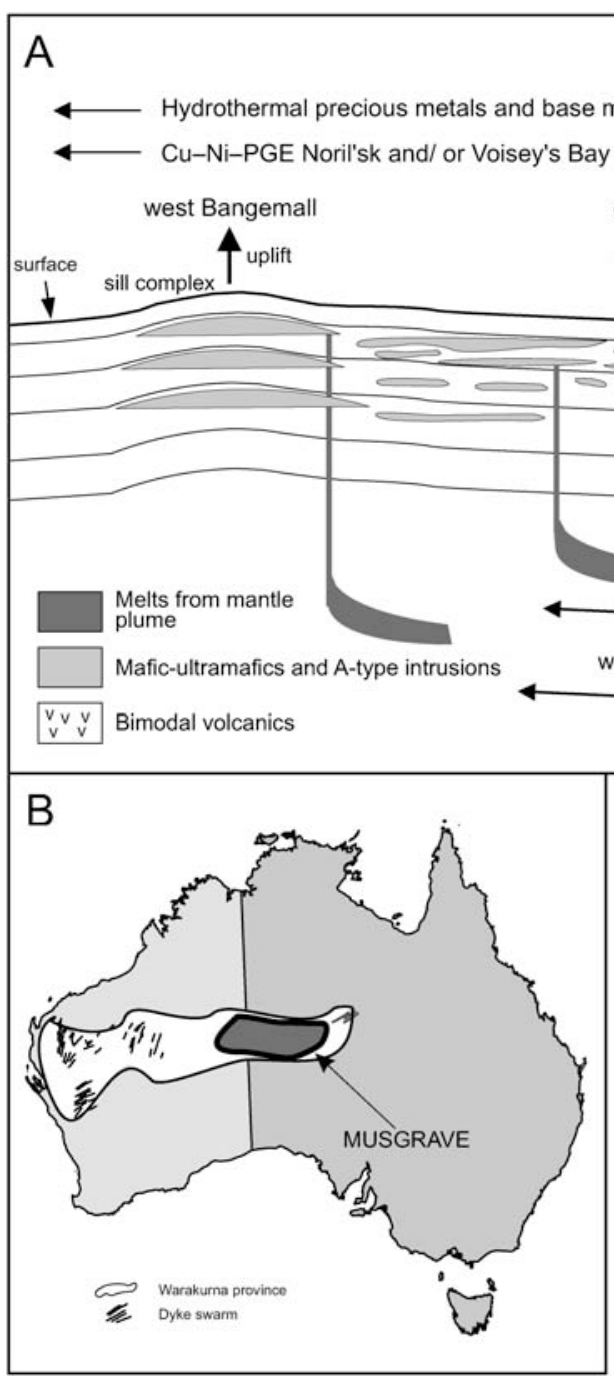

( 2.7-2.5 Ga; e. g. rift systems of the Fortescue, Western Australia, and Ventersdorp, South Africa). These rift systems act as major conduits for both magmas and hydrothermal fluids and riftrelated ore deposits are characterized by metal associations that reflect the interaction of anorogenic magmas and the rifts' volcano-sedimentary successions. Examples of rift systems that are well-endowed with hydrothermal ore deposits are, the 1.1 Ga MidContinent rift system (USA; Nicholson et al., 1992), the Jurassic Limpopo-Sabi-Lebombo triple junction rifts (southern Africa; Pirajno, 2000), the Mesozoic Panxi rift and the midProterozoic Langshan-Bayunobo rift (both in China; Gilder et al., 1991), which hosts the worldclass Bayan Obo REE deposit (Table 2). Volcano-sedimentary successions of rift basins host a great variety of hydrothermal ore deposits as well as hydrocarbon reservoirs. Sn-W exoskarns, formed in carbonate successions and typically associated with intrusion-related greisen style alteration, are generally associated with rifting of stable cratons due to impacting mantle plumes (Meinert et al., 2005). Sedimentary-rock hosted metalliferous ore deposits (e. g. Pb-Zn-Ba-CuAu-Ag; SEDEX) typically occur in intracontinental rift basins (Figure 6). Well-known exam-

its flow towards craton-mobile belt boundaries, where at depths of $>150 \mathrm{~km}$ small volumes of melt can be produced by decompression. Kimberlite and lamproites are well known for their diamondiferous potential, whereas carbonatite may host important resources of rare metals, REE and $\mathrm{Cu}$ (Pirajno, 2000).

\section{Hydrothermal ore systems}

The wider link between hydrothermal ore deposits and mantle plumes is explored in this section. In addition to direct generation of magmas, thermal anomalies associated with deep mantle plumes or upwelling of asthenospheric mantle constitute powerful heat sources in the crust. These are responsible for crustal scale hydrothermal circulation and high-T and low-P metamorphism, which may result in a wide range of ore deposits in rift systems that form as result of these mantle processes.

In the sedimentary basins of the Capricorn Orogen in Western Australia there are numerous vein deposits and their genesis has been attributed to regional scale hydrothermal convection related to heat energy resulting from the emplacement of sill complexes of the 1076 Ma Warakurna LIP in central Western Australia (Pirajno, 2004b; Pirajno et al., 2006). Similarly, the thermal energy released during cooling of the Bushveld Igneous Complex in South Africa, activated crustal-scale hydrothermal convection cells from which many $\mathrm{Sn}, \mathrm{Cu}, \mathrm{Au}$ and $\mathrm{W}$ vein deposits formed in the surrounding rocks of the Transvaal basin (Pirajno, 2000).

The geological record shows several rift systems associated with LIPs, at least since the Neoarchaean-Palaeoproterozoic ples of SEDEX deposits of rift basins include, Gamsberg-Aggenays in South Africa; McArthur River, Broken Hill, Hilton, Lady Loretta, Mt. Isa in Australia; Sullivan in Canada, to mention a few. Although the origin of these intracontinental rift basins may be linked to backarc rifts or delamination tectonics associated with far field stresses, it is interesting to note that the majority of SEDEX deposits formed between the early and mid-Proterozoic $(\sim 1.9-1.0 \mathrm{Ga})$, which coincide with global or superplume events at $1.9,1.6,1.2-1.3,1.1 \mathrm{Ga}$ (Ernst and Buchan, 2002). A modern analogue of metalliferous sediments is provided by Red Sea brine pools (see review by Gurvich, 2006). The Red Sea can be considered as the northern arm of the great, 5000 km-long, East African Rift System (EARS). The EARS provides a window into what must be a giant intracontinental ore making factory, comparable to present-day oceanic spreading centers. The tectonic and magmatic environments of the EARS are schematically illustrated in Figure 6. The EARS includes sulphide deposits in the Red Sea brine pools, hydrothermal sediments deposits in rift lakes, and perhaps deep-seated anorogenic magmatic systems beneath the rift floors.

\section{Carlin style ore systems}

Since its discovery in 1962 the Carlin deposit, of Tertiary age, in Nevada (western USA) has lent its name to a type of fine-grained disseminated $\mathrm{Au}-\mathrm{Ag}$ hydrothermal mineralisation, hosted by carbonate rocks. The discovery of similar deposits elsewhere, made it clear that Carlin was most probably an end-member of a group of deposits that displays considerable variations in their geological, mineralogical and geochemical features. Carlin-type deposits are also present in 

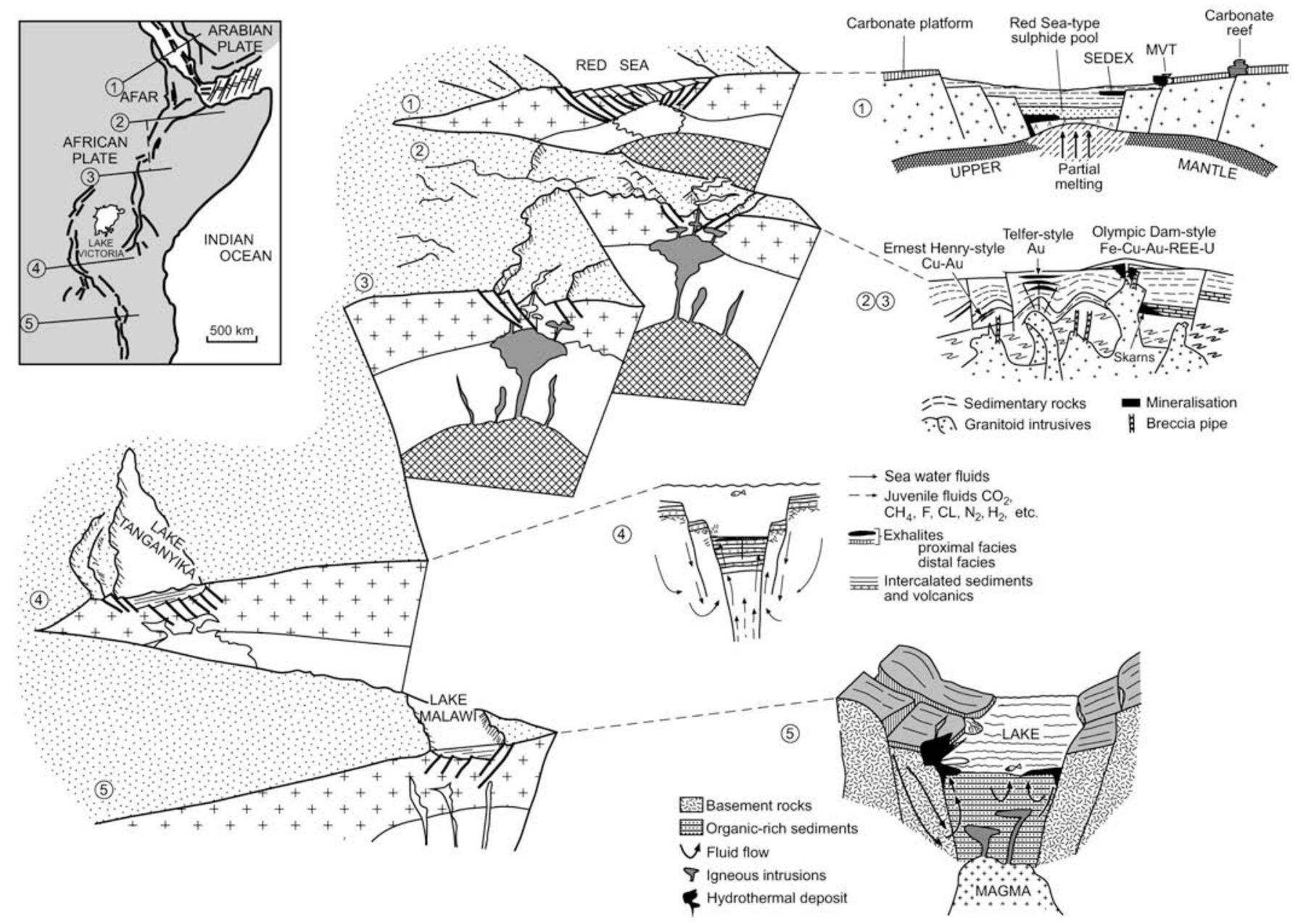

Figure 6 Schematic illustration of the East African Rift System and hypothetical ore systems that may be associated with it. 1) the advanced Red Sea rift, where oceanic crust is being emplaced and where pools of brines and sulphides are actively forming; 2) and 3) represent a continental rift with anorogenic alkaline magmas at depth, from which magmatic and hydrothermal deposits of the Fe oxideCu-Au style may be forming (names of deposits in the figure refer to well-known Australian examples). 4) represents a rift system with a deep lake in which sediments and volcanic materials accumulate together with subaqueous exhalites. 5) also a rift-lake system, where sediments are organic-rich and where subaqueous hydrothermal venting occurs. After Pirajno (2004a and references therein).

southern China and in Iran (Pirajno 2000 and references therein). An overview of the controversies surrounding the origin of Carlin style ore systems is provided by Muntean et al. (2004), with ore deposit models ranging from magmatic (intrusion-related) to amagmatic (Ilchik and Barton, 1997). A recent review of the Carlin ore systems is provided by Cline et al. (2005). In Nevada, most deposits are within the Basin-and-Range province, situated between the Colorado Plateau in the east and the Sierra Nevada in the west. Oppliger et al. (1997) linked the Carlin-type deposits with the Yellowstone hotspot. They argued that the impingement of the Yellowstone plume beneath north-central Nevada in the Eocene, resulted in metasomatism, thermal weakening of the lithosphere and magmatism. This, in turn, caused metamorphic devolitilasation of the lower crust and widespread hydrothermal convective circulation in the upper crust. A mantle plume origin for the Carlin ore systems is supported by $\mathrm{He}$ isotope systematics (Cline et al., 2005).

\section{Low-sulphidation epithermal systems associated with LIPs}

Epithermal systems are typically found in subduction-related volcanic arc settings and are classified into four types: 1) high-sulphidation; 2) intermediate-sulphidation; 3) low-sulphidation and 4) alkalic (Simmons et al. 2005). Some low-sulphidation adulariasericite and alkalic epithermal systems are now becoming increasingly recognised in other geotectonic settings, including continental volcanic provinces, such as LIPs. Examples of low-sulphidation sys- tems that are associated with LIPs can be found in NW China and in silicic LIPs (see Bryan, this issue). The Axi and Jinxi-Yemand epithermal Au deposits (Rui et al., 2002) occur in the Ili Block, which represents a Carboniferous-Permian continental rift system associated with widespread continental tholeiitic flood volcanism (Xia et al., 2004).

The previously mentioned Great Basin (Basin-and-Range province) in the western USA is a high plateau terrain, formed by extensional tectonics, which extends from the western USA to Mexico. Parsons (1995) gave a comprehensive account of the geological and geophysical features of the province. Magmatic activity in the province began about $55 \mathrm{Ma}$ ago, and, although highly variable in its products, it is typically bimodal. Various lines of evidence, including gravity and seismic data, suggest that the Basin-and-Range is underlain by upwelling asthenosphere, which accounts for the nature and composition of the volcanism, its elevated topography and the ongoing hydrothermal activity. To explain the tectonic evolution of the Basin-and-Range, Parsons (1995) considered four possibilities: 1) back-arc extension; 2) orogenic thickening; 3) passive rifting; and 4) the Yellowstone mantle plume. The Yellowstone hotspot is a likely control because of the broad topographic elevation and the low-density mantle interpreted from geophysical data. The North American plate moved southwestward, over the Yellowstone hotspots during the last $17 \mathrm{Ma}$, producing the Snake River Plain and Columbia flood basalts. John (2001), who studied the northern part of the Great 
Basin, distinguished two main igneous assemblages, an older andesite and a younger (17 Ma to present) bimodal basalt-rhyolite, which reflect different tectonic environments, namely subductionrelated and continental rifting, respectively. The bimodal assemblage is host to numerous Au-Ag low sulphidation epithermal deposits.

\section{Volcanic-hosted massive sulphide deposits}

Volcanic-hosted massive sulphide deposits (VMS) form at or near the sea floor by hydrothermal exhalations that are genetically and spatially associated with submarine volcanism (Franklin et al., 2005). The main tectonic settings of VMS deposits are arc-back arc systems related to subduction. However, in the East Pilbara Terrane are the oldest $(\sim 3.5 \mathrm{Ga})$ volcanic-hosted massive sulphide deposits, which include the Whim Creek-Mons Cupri and the Panorama VMS hydrothermal system (Brauhart et al., 2000; Huston, 2006). The East Pilbara Terrane contains a succession of greenstone rocks, mainly characterised by komatiites and associated felsic units, which accumulated between 3.51 and $2.95 \mathrm{Ga}$ and are interpreted to have formed by intense Early Archaean mantle plume activity that formed a series of stacked oceanic plateaux (Smithies et al., 2005). The East Pilbara VMS deposits were formed in a seafloor related to an oceanic plateau environment. It is possible that VMS systems may also be present in post-Archaean bimodal volcanic terranes that were part of an oceanic plateau.

\section{Iron-formations}

Voluminous iron-formations accumulated in the period 2.6-1.8 $\mathrm{Ga}$ in intracratonic passive margins or platform basins during periods of high sea-level stands (Groves et al. 2005). Most authors agree that banded iron-formations (BIF) may owe their origin to vigorous and intense hydrothermal effluents, probably from mid-ocean ridges and submarine LIPs (oceanic plateaux). BIF are chemical-sedimentary units containing in excess of $15 \% \mathrm{Fe}$, or $30 \% \mathrm{Fe}$-oxides, consisting of $\mathrm{Fe}$ oxides (hematite and/or magnetite) alternating with chert and silica bands. Clastic iron-formations, due to the re-working of BIF in shallow waters, are known as granular iron-formation (GIF) (Trendall, 2002). The best-known Superior-type iron-formations, in terms of both geological interest and economic value are those of the Transvaal Supergroup (South Africa), the Hamersley Group (Western Australia), the Minas Gerais (Quadrilatero Ferrifero Brazil), the Krivoy Rog basin (Ukraine) and the classic Gunflint, Biwabik and Sokoman iron-formations of the Lake Superior region in North America. Literature on iron-formations is voluminous, and a useful and comprehensive review is provided by Trendall (2002). Superior-type iron-formations are most abundant in the Late Archaean-Early Proterozoic, although iron-formations are also known from the Early Archaean and the Phanerozoic. The Proterozoic iron-formations are commonly associated with giant manganese deposits, such as those of the $2.2 \mathrm{Ga}$ Kalahari Mn field in South Africa (the largest in the world with about 13 billion tonnes of ore) and Minas Gerais in Brazil. This close spatial relationship is related to the chemical affinity of $\mathrm{Fe}$ and $\mathrm{Mn}$ and therefore the same solutions that are enriched in $\mathrm{Fe}$ are also enriched in Mn (Cornell and Schütte, 1995). The origin of the iron and manganese formations requires that large amounts of these metals be brought into solution as reduced species $\left(\mathrm{Fe}^{2+}\right.$ and $\left.\mathrm{Mn}^{2+}\right)$, which are then oxidised $\left(\mathrm{Fe}^{3+}\right.$ and $\mathrm{Mn}^{3+}, \mathrm{Mn}^{4+}$ ) and precipitated as $\mathrm{Fe}$ and $\mathrm{Mn}$ oxides and carbonates. Deposition of BIF reached maxima at about 2.7 and $1.9 \mathrm{Ga}$, which coincide with maxima in mantle plume activity (Isley and Abbott, 1999). The $1.9 \mathrm{Ga}$ superplume event also coincides with peak production of black shales and the deposition of intracratonic sediments in sag basins and continental shelves (Condie, 2001; 2005).

\section{Concluding remarks}

The mantle plume theory is based on a combination of surface observations of large topographic swells, intraplate anorogenic magmatism and geophysical data (e.g. seismic tomography). The theory holds that plumes of hotter than normal mantle material may originate from thermal boundary layer instabilities, at the $670 \mathrm{~km}$ discontinuity and from the core-mantle boundary (CMB). The mantle plume theory provides a global framework for the understanding of intraplate tectono-magmatic and ore-forming processes, as well as continental assembly, breakup and rifting. In the Archaean, mantle plumes were hotter and underwent higher degrees of melting, hence the common komatiitic components. It follows that the pattern of mantle convection changed with time from whole mantle to twolayer convection, causing changes in the driving mechanisms that control plate movements and consequently the diverse patterns of Archaean, Proterozoic and Phanerozoic tectonics (Groves et al., 2005; Condie, 2005; Pirajno, in press). As discussed in this paper, mantle plume events result in the emplacement of LIPs, characterised by vast outpourings of dominantly tholeiitic basalt lavas in, geologically, very short times. These form oceanic plateaux and chains of volcanic islands on the sea floor, and continental flood basalts on land. Seismic data indicate that layered mafic-ultramafic intrusions constitute a large proportions of a LIP, and what we see in present-day outcrops of LIP may only be the "tip of the iceberg". This implies that outcropping fossil magma chambers (e.g. layered complexes and sill complexes), probably represent the roots of what must have been ancient LIP, whereas dyke swarms represent the feeders.

Thus, mantle plume-related intraplate magmas directly or indirectly are involved in the making of a wide range ore deposits. These include magmatic ore deposits that form in magma chambers, or in feeders or in lava channels, and magmatic-hydrothermal ore systems in a variety of tectonic settings, from anorogenic igneous complexes, including carbonatites and kimberlites, that complement and accompany many LIPs, to those that form by the circulation of fluids in giant hydrothermal systems in rift zones, themselves originated by the impact of mantle plumes onto the base of the lithosphere. The introduction to the crust via mafic-ultramafic melts, of siderophile and chalcophile elements can be directly linked to mantle upwellings to the lithosphere. Further concentration and/or selective uptake of these elements takes place during hydrothermal convection in the crust, with the heat supplied by mantle-derived magmas.

In the final analysis, there is now far greater acceptance of the importance of the involvement of mantle dynamics in the inception of both magmatic and hydrothermal mineral systems than previously realized.

\section{Acknowledgements}

I thank the organisers of IAVCEI 2006 International Conference on Continental Volcanism held in Guangzhou, China. In particular I wish to thank Dr. Xu Yigang and Prof. Ian H. Campbell, for inviting me. Ian Campbell also provided useful and constructive criticism of this paper. I received financial support from the NSFC project No. 40425006, granted to Prof. Y.J. Chen. Thanks are due Eunice Cheung for her invaluable help with interlibrary requests and to Nell Stoyanoff for typing the tables. Murray Jones drafted the figures. This paper is published with the permission of the Executive Director of the Geological Survey of Western Australia. 


\section{References}

Abbott, D.H., Burgess, L., Longhi, J., Smith, W.H.F., 1995, An empirical thermal history of the Earth's upper mantle: Journal of Geophysical Research, v. 99 , pp. $13835-13850$.

Abbott, D.H., Isley, A.E., 2001, Oceanic upwelling and mantle plume activity: paleomagnetic tests of ideas on the source of the Fe in early Precambrian iron formations: Geological Society of America Special Paper 352, pp. 323-339.

Abbott, D.H., Isley, A.E., 2002, The intensity, occurrence, and duration of superplume events and eras over geological time: Journal of Geodynamics, v. 34, pp. 265-307.

Arndt, N.T,. 1994, Archean komatiites, in KC Condie (ed) Archean crustal evolution, Elsevier, Amsterdam, pp 11-44

Ballentine, C.J., Marty, B., Sherwood Lollar, and B., Cassidy, M., 2005, Neon isotopes constrain convection and volatile origin in the Earth's mantle: Nature, v. 433, pp. 33-38.

Baragar, W.R.A., Ernst, R.E., Hulbert, L., Peterson, T., 1996, Longitudinal petrochemical variation in the Mackenzie Dyke Swarm, Northwestern Canadian Shield: Journal of Petrology, v. 37, pp. 317-359.

Barberi, F, Varet, J., 1978, The Afar rift junction, in Neumann R Ramberg IB (eds), Petrology and geochemistry of continental rifts, Reidel, Dordrecht, pp.55-69.

Barley, M.E., Groves, I., 1992, Supercontinent cycles and the distribution of metal deposits through time: Geology v. 20, pp. 291-294.

Barnes, S.J., Hill, R.E.T., Perring, C. S., Dowling, S.E., 1999, Komatiite flow fields and associated $\mathrm{Ni}$-sulphide mineralization with examples from the Yilgarn block, Western Australia: Geological Association of Canada Short Course Notes 13, pp. 159-194.

Barnes, S.J., Maier, W.D., 1999, The fractionation of $\mathrm{Ni}, \mathrm{Cu}$ and the noble metals in silicate sulphide liquids: Geological Association of Canada Short Course Notes 13, pp. 69-106.

Becker, L., 2002, Repeated blows: Scientific American, v. 286, pp. 62-69.

Bell, K., 2001, Carbonatites: relationship to mantle plume activity: Geological Society of America Special Paper 352, pp. 267-290.

Boudreau, A.E., McCallum, I. S., 1992, Concentration of Platinum - Group Elements by magmatic fluids in layered intrusions: Economic Geology, v. 87, pp. $1830-1848$

Brauhart, C.W., Huston, D.I., Andrews, A.S., 2000, Oxygen isotope mapping in the Panoroma VMS district, Pilbara Craton, Western Australia: applications to estimating temperatures of alteration and to exploration: Mineralium Deposita, v. 35, pp. 727-740.

Bryan, S., Riley, T.R., Jarram, D.A., Leat, P. T., Stephens, C. J., 2002, Silicic volcanism: an undervalued component of large igneous provinces and volcanic rifted margins; Geological Society of America Special Paper 362, pp. 99-120.

Bryan, S., 2007, Silicic large igneous provinces, Episodes, Vol. 30, No. 1.

Burke, K., Dewey, J. F., 1973, Plume generated triple junctions: key indicators in applying plate tectonics to old rocks: Journal of Geology, v. 81, pp. 406-433.

Campbell, I.H., 2005, Large igneous provinces and the mantle plume hypothesis: Elements, v. 1, pp. 265-270.

Campbell, I.H., Griffiths, R.W., Hill, R.I. 1989, Melting in an Archaean mantle plume: heads it's basalts, tails it's komatiites: Nature v. 339, pp. 697-699.

Campbell, I.H., Griffiths, R.W., 1990, Implications of mantle plume structure for the evolution of flood basalts: Earth and Planetary Science Letters, v. 99 , pp. 79-93

Campbell, I.H., Hill, R.I., 1988, A two-stage model for the formation of granite-greenstone terrains of the Kalgoorlie-Norseman area, Western Australia: Earth Planetary Science Letters, v. 90, pp. 11-25.

Campbell, I.H., Davies, G.F., 2006, Do mantle plumes exist? Episodes, v. 29, pp. 162-168.

Chen, Y-J., Pirajno, F., Sui, Y-H., 2004, Isotope geochemistry of the Tieluping silver-lead deposit, Henan, China: A case study of orogenic silver-dominated deposits and related tectonic setting: Mineralium Deposita, v. 39, pp. $56-573$.

Cline, J.S., Hofstra, A.H., Muntean, J. L., Tosdal, R.M., Hickey, K.A., 2005, Carlin-type gold deposits in Nevada: critical geologic characteristics and viable models: Economic Geology, 100th Anniversary Volume, pp. 451-484.

Coffin, M.F., Eldhom, O., 1992, Volcanism and continental breakup: a global compilation of large igneous provinces: Geological Society, London, Special Publication 68, pp. 17-30.

Condie, K.C., 2001, Mantle plumes and their record in Earth history: Cambridge University Press. 306pp.
Condie, K.C., 2003, Incompatible element ratios in oceanic basalts and komatiites: tracking deep mantle sources and continental growth rates with time: Geochemistry Geophysics Geosystems 4: 10.1029/2002GC000333.

Condie K.C., 2004, Supercontinents and superplume events: distinguishing signals in the geologic record: Physics of the Earth and Planetary Interiors, v. 146, pp. 319-332.

Condie, K.C., 2005, Earth as an evolving planetary system: Elsevier, Academic Press, Amsterdam, 447pp.

Cornell, D.H., Schülte, S. S., 1995, A volcanic-exhalative origin for the world's largest (Kalahari) manganese field: Mineralium Deposita, v. 30, pp. 146-151.

Courtillot, V., Davaille, A., Besse, J., Stock, J., 2003, Three distinct types of hotspots in the Earth's mantle: Earth Planet Science Letters, v. 205, pp. 295-308

Davies, G.F., 1999, Dynamic Earth-Plates, plumes and mantle convection: Cambridge University Press, $458 \mathrm{pp}$.

Davies, G.F. and Richard, M.A., 1992, Mantle convection: Journal of Geology, v. 100, pp.151-206

de Witt, M.J., 1998, On Archean granites, greenstones, cratons and tectonics: does the evidence demand a verdict?: Precambrian Research, v. 91, pp. $181-226$.

Ebinger, C.J., Sleep, N.H., 1998, Cenozoic magmatism throughout East Africa resulting from impact of a single plume: Nature, v. 395, pp. 788-791.

Eldhom, O., Grue, K., 1994, North Atlantic volcanic margin: dimensions and production rates: Journal of Geophysical Research, v. 99, pp. 2955-2968.

Elkins-Tanton, L.T., 2005, Continental magmatism caused by lithospheric delamination: Geological Society Of America, Special Papper 388, pp. $449-61$.

Elliot, D.H., Fleming, T.H., Kyle, P.R., Foland, K.A., 1999, Long distance transport of magmas in the Jurassic Ferrar large igneous province, Antarctica: Earth Planetary Science Letters, v. 167, pp. 89-104.

Ernst, R.E., Buchan, K.L., Campbell, I.H., 2005, Frontiers in large igneous province research: Lithos, v. 79, pp. 271-97.

Ernst, R.E., Buchan, K., 2001, Large mafic magmatic events through time and links to mantle plume heads: Geological Society of America Special Paper 352 , pp. pp. $483-566$.

Ernst, R.E., Buchan, K.L., 2002, Maximum size and distribution in time and space of mantle plumes: evidence from large igneous provinces: Journal of Geodynamics, v. 34, pp. 309-342.

Ernst, R.E., Buchan, K., 2003, Recognising mantle plumes in the geological record: Annual Review, Earth and Planetary Sciences, v. 31, pp. 469-523.

Ernst, R.E., Head, J.W., Parfitt, E., Grosfils, E., and Wilson, L., 1995, Giant radiating dyke swarms on Earth and Venus. Earth - Science Reviews v. 39, pp. $1-58$.

Foulger, G.R., Natland, J.H., Presnell, D.C, and Anderson, D.L., 2005, Plates, plumes and paradigms: The Geological Society of America Special Paper 388.

Franklin, J.M., Gibson, H.L., Jonasson, I.R., and Galley, D.A., 2005, Volcanogenic massive sulfide deposits:. Economic Geology, 100th Anniversary Volume, pp. 523-560.

Gilder, S.A., Keller, G.R., Luo, M., Goodell, P.C., 1991, Timing and spatial distribution of rifting in China. Tectonophysics v. 197, pp. 225-243.

Glass, L.M., Phillips, D., 2006, The Kalkarindji continental flood basalt province in Australia with possible links to faunal extinctions: Geology, v. 34, pp. 461-464.

Griffiths, R.W., Campbell, I.H., 1990, Stirring and structure in mantle plumes. Earth Planetary Science Letters, v. 99, pp. 66-78.

Griffiths, R.W. \& Campbell, I.H., 1991. Interaction of mantle plume heads with the Earth's surface and onset of small-scale convection, Journa of Geophysical. Research, v. 96(B11), pp. 18295-18310.

Groves, D.I., Vielreicher, R.M., Goldfarb, R.J., Condie, K.C., 2005, Controls on the heterogeneous distribution of mineral deposits through time. Geological Society, London, Special Publication v. 248, pp. 71-101.

Gurnis, M., Mitrovica, J.X., Ritsema, J., van Heijst, H-J., 2000, Constraining mantle density structure using geological evidence of surface uplift rates: the case of the African Superplume: Geochem Geophys Geosyst 1, Pap no 1999GC000035.

Gurvich, E.G., 2006, Metalliferous sediments of the world ocean: Springer, Berlin, 416pp.

Hamlyn, P.R., Keays, R.R., 1986, Sulfur saturation and second-stage melts: application to the Bushveld platinum metal deposits: Economic Geology, v. 81, pp. $1431-1445$.

Hill, R.I., Campbell, I.H., Griffiths, R.W., 1991, Plume tectonics and the development of stable continental crust: Exploration Geophysics, v. 22:, pp. $185-188$.

Hill, R.I., Barnes, S.J., Gole, M.J., Dowling, R.W., 1990, Physical volcanology of komatiites: Geological Society of Australia Excursion Guide Book 1. 
Hitzman, M.W., Oreskes, N., Einaudi, M.T., 1992, Geological characteristics and tectonic setting of Proterozoic iron oxides (Cu-U-Au-REE) deposits: Precambrian Research, v. 58, pp. 241-287.

Hofmann, A.W.,1997, Mantle geochemistry: the message from oceanic volcanism. Nature, v. 385, pp. 219-229.

Huston, D.L., 2006, Mineralization and regional alteration at the Mons Cupri stratiform $\mathrm{Cu}-\mathrm{Zn}-\mathrm{Pb}$ deposit, Pilbara Craton, Western Australia: Mineralium Deposita, v. 41, pp. 17-32.

Ilchik, R.P., Barton, M. D., 1997, An amagmatic origin of Carlin-type gold deposits: Economic Geology, v. 92, pp. 269-288.

Isley, A.E. and Abbott, D.H., 1999, Plume-related mafic volcanism and the deposition of banded iron formation: Journal of Geophysical Research, v. 104, pp. $15461-15477$.

Jacobs. J.A., 1992, Deep interior of the Earth. London; New York: Chapman \& Hall, $167 \mathrm{pp}$

Jahren, A.H., 2002, The biogeochemical consequences of the mid-Cretaceous superplume: Journal of Geodynamics, v. 34, pp. 177-191.

John, D.A., 2001, Miocene and Early Pliocene epithermal gold-silver deposits in the northern Great Basin, Western United States: characteristics, distribution and relationship to magmatism: Economic Geology, v. 96, pp. 1827-1853.

Jones, A.P., Price, G.D., Price, N.J., DeCarli, P.S., Clegg, R.A., 2002, Impact induced melting and the development of large igneous provinces: Earth Planetary Science Letters, v. 202, pp. 551-561.

Kinnaird, J.A., Bowden, P. (eds), 1987, African Geology Reviews: Geological Journal, v.22.

Klausen, M.B., Larsen, H.C., 2002, East Greenland coast-parallel dike swarms and its role in continental breakup: Geological Society of America Special Paper 362, pp. 133-158.

Lambert, D.D., Foster, S.G., Frick, R.L., Ripley, E.M., Zienterk, M.L., 1998, Geodynamics of magmatic Cu-Ni-PGE sulfide deposits: new insights from the Re-Os system: Economic Geology, v.93, pp. 121-137.

Larson, R.L., 1991, Latest pulse of the Earth: evidence for a mid-Cretaceous superplume: Geology, v. 19, pp. 547-550.

Le Maitre, R.W. (ed), 2002, Igneous rocks-A classification and glossary of terms: Cambridge Univesity Press.

Lesher, C.M., Keays, R.R., 2002, Komatiite-associated Ni-Cu-(PGE) deposits: geology, mineralogy, geochemistry and genesis: Canadian Institute of Mining Metallurgy and Petroleum Special Volume 54, pp. 579-617.

Li, C., Naldrett, A.J., 1999, Geology and petrology of the Voisey's Bay intrusion: reaction of olivine with sulfide and silicate liquids: Lithos, v. 47, pp. $1-31$.

Li, C., Maier, W.D., de Waal, S.A., 2001, Magmatic Ni-Cu versus PGE deposits: contrasting genetic controls and exploration implications: South African Journal of Geology, v. 104, pp. 309-318.

Maier, W.D., 2000, Platinum-group elements in $\mathrm{Cu}$-sulphide ores at Caralusberg and East Okiep, Namaqualand, South Africa: Mineralium Deposita, v. 35, pp. 422-430.

Marzoli, A., Renne, P.R., Piccirillo, E.M., Ernesto, M., Bellieni, G., and De Min, A., 1999, Extensive 200-million year old continental flood basalts of the Central Atlantic Magmatic Province: Science v. 284, pp. 616-618.

Mats, V. D., 1993. The structure and development of the Baikal rift depression. Earth Science Reviews v. 34, pp. 81-118.

Meinert, L.D., Dipple, G.M., Nicolescu, S. 2005, World skarn deposits: Economic Geology 100th Anniversary Volume, pp. 299-336.

Mohr, P., 1978, Afar: Annual Reviews Earth Planetary Science, v. 6, pp. $145-172$

Montelli R, Nolet, G., Dahlen, F.A., Masters, G., Engdahl, E.R., and Hung, SH., 2004 , Finite-frequency tomography reveals a variety of plumes in the mantle: Science v. 303, pp. 338-343.

Morris, P.A. and Pirajno, F., 2005, Geology, geochemistry and mineralization of Mesoproterozoic sill complexes of the Bangemall Supergroup, Western Australia Geological Survey Report 99.

Muntean, J.L., Cline, J., Johnston, M.K., Ressel, M.W., Seedorff, E., and Barton, M.D., 2004, Controversies on the origin of world-class gold deposits, Part I: Carlin-type gold deposits in Nevada: SEG Newsletter, v. 59, pp. $1-18$.

Naldrett, A.J., 1997, Key factors in the genesis of Noril'sk, Sudbury, Jinchuan, Voisey's Bay and other world class Ni-Cu-PGE deposits: implications for exploration: Australian Journal of Earth Sciences, v. 44, pp 283-316.

Nicholson, S.W., Cannon, W.F., Schulz, K.J., 1992, Metallogeny of the Midcontinent rift system of North America: Precambrian Research, v. 58, pp. 355-386.

Nikishin, A.M., Ziegler, P.A., Abbott, D., Brunet, M.F., and Cloetingh, S., 2002, Permo-Triassic intraplate magmatism and rifting in Eurasia: implications for mantle plumes and mantle dynamics: Tectonophysics, v. $351 \mathrm{pp}$. 3-39.
Nolet, G., Karato, S-I., Montelli, R., 2006, Plume fluxes from seismic tomography: Earth and Planetary Science Letters, v. 248, pp. 685-99.

Oppliger, G.L., Murphy, J.B., Brimhall, G. H., 1997, Is the ancestral Yellowstone hotspot responsible for the Tertiary "Carlin" mineralization in the Great Basin of Nevada?: Geology, v. 25, pp. 627-630.

Parsons, T.,1995, The Basin and Range province, in Olsen, K.H. (ed) (1995) Continental rifts: evolution, structure, tectonics: Elsevier, Amsterdam, pp.277-324.

Perfit, M.R., Davidson, J. P., 2000, Plate tectonics and volcanism, in Sigurdson H. et al (eds), Encyclopedia of volcanoes: Academic Press, San Diego, pp 89-113

Pirajno, F., 1992, Hydrothermal mineral deposits: Sprinver-Verlag, Berlin, $709 \mathrm{pp}$.

Pirajno, F., 2000, Ore deposits and mantle plumes: Kluwer Academic Publishers, Dordrecht, 556pp.

Pirajno, F., 2004a, Hotspots and mantle plumes: global intraplate tectonics, magmatism and ore deposits: Mineralogy and Petrology, v. 82, pp. $183-216$.

Pirajno, F., 2004b,. Metallogeny in the Capricorn Orogen, Western Australia, the result of multiple ore-forming processes: Precambrian Research, v. 128, pp. 411-440.

Pirajno, F., 2006, Mantle dynamics and intraplate tectonics, magmatism and ore systems: IAVCEI 2006 International Conference on Continental Volcanism, Abstracts and Programs, Guangzhou, China, p. 176.

Pirajno, F., in press, Ancient to modern Earth: the role of mantle plumes in the making of continental crust, in Van Kranendonk M.J., Smithies, R.H., Bennett, V. (eds) Earth's oldest rocks: Elsevier, Amsterdam.

Pirajno, F., Smithies, H.R., Howard, H.M., 2006, Mineralisation associated with the $1076 \mathrm{Ma}$ Giles mafic-ultramafic intrusions, Musgrave Complex, central Australia: a review: SGA News, v. 20, pp. 1-20.

Richards, J.P., 1995, Alkalic-type epithermal gold deposits - A review: Mineralogical Association of Canada - Short Course 23, pp. 367-400

Rogers, N., Macdonald, R., Fitton, J.G., George, R., Smith, M.m Barreiro, B., 2000, Two mantle plumes beneath the East African rift system: Sr, Nd and $\mathrm{Pb}$ isotope evidence from Kenya rift basalts: Earth and Planetary Science Letters, v. 176, pp. 387-400.

Reiners, P.P.W., 2002, Temporal-compositional trends in intraplate basalts eruptions: implications for mantle heterogeneity and melting processes: Geochemistry Geophysics Geosystems 3: 10.1029/2001GCC000250.

Ripley, E.M., Li, C., Shin, D., 2002, Paragneiss assimilation in the genesis of magmatic Ni-Cu-Co sulfide mineralisation at Voisey's Bay, Labrador: $\delta^{34} \mathrm{~S}, \delta^{13} \mathrm{C}$ and Se/S evidence: Economic Geology, v. 97, pp. 1307-1318.

Rui, Z-Y., Goldfarb, R.J., Qiu, Y-M., Zhou, T-H., Chen, R-Y., Pirajno, F., Yun, G., 2002, Paleozoic-early Mesozoic gold deposits of the Xinjiang Autonomous Region, northwestern China: Mineralium Deposita, 37, pp. 393-418.

Rogers, N., Macdonald, R., Fitton, J.G., George, R., Smith, M., Barreiro, B., 2000, Two mantle plumes beneath the East African rift system: Sr, Nd and $\mathrm{Pb}$ isotope evidence from Kenya rift basalts: Earth Planet Science Letters v. 176, pp. 387-400.

Samuel, H., Farnetani, C.G., 2003, Thermochemical convection and helium concentrations in mantle plumes: Earth and Planetary Science Letters, v. 207, pp. 39-56.

Schubert, G., Turcotte, D.L., Olson, P.P., 2001, Mantle convection in the Earth and planets: Cambridge University Press, Cambridge, 939pp.

Schneider, G.I.C., 1992, The Kunene Complex, in Mineral Resources of Namibia, 1st ed: Ministry of Mines and Energy, Republic of Namibia, pp 6-26.

Seat, Z., Beresford, S.W., Grguric, B.A., Waugh, R.S., Hronsky, J.M.A., Gee, M.A.M., Groves, D.I., Mathison, C.I., in press, Architecture and emplacement of the world-class Nebo-Babel gabbronorite-hosted magmatic $\mathrm{Ni}-\mathrm{Cu}$ PGE system, West Musrgrave, Western Australia: Mineralium Deposita.

Sengör, A.M.C., 2001, Elevation as indicator of mantle plume activity: Geological Society of America Special Paper 352, pp. 183-225.

Sengör, A.M C., Burke, K., Dewey, J. F., 1978, Rifts at high angles to orogenic belts: tests for their origin and the upper Rhine graben as an example: American Journal of Science, v. 278, pp. 24-40.

Simmons, S.F., White, N.C., John, D.A., 2005, Geological characteristics of epithermal precious and base metal deposits: Economic Geology 100th Anniversary Volume, pp. 485-522.

Smithies, R.H., van Kranendonk, M.J., Champion, D. C., 2005, It started with a plume-early Archaean basaltic proto-continental crust: Earth and Planetary Science Letters 238: 284-297.

Storey, M., Mahoney, J.J., Kroenke, L.W., Saunders, A.D., 1991, Are oceanic plateaus sites of komatiite formation?: Geology, v. 19, pp. 376-379.

Taylor, P., 2006, The single largest oceanic plateau: Ontong-Java-ManihikiHikurangi: Earth and Planetary Science Letters, 241, pp. 372-397. 
Tomlinson, K.Y., Stevenson, R.K., Hughes, D.J., Hall, R.P., Thurston, P.C., Henry, P., 1998, The Red Lake greenstone belt, Superior Province: evidence of plume-related magmatism at $3 \mathrm{Ga}$ and evidence of an older enriched source: Precambrian Research, v. 89, pp. 59-76.

Trendall, A.F., 2002, The significance of iron-formation in the Precambrian stratigraphic record: International Association Sedimentologists Special Publication, v. 44, pp. 33-66.

Wallace, P.J., Frey, F.A., Weis, D., Coffin, M.F., 2002, Origin and evolution of the Kerguelen Plateau, Broken Ridge and Kerguelen archipelago: editorial: Journal of Petrology, v. 43, p. 1105-118.

Walter, M.R., Veevers, J.J., Calver, C.R., Grey, K., 1995, Neoproterozoic stratigraphy of the Centralian Superbasin, Australia: Precambrian Research, v. 73, pp. 173-195.

White, N., Lovell, B., 1997, Measuring the pulse of a plume with the sedimentary record: Nature, v. 387, pp. 888-891.

White, R.V., Saunders, A.D., 2005, Volcanism, impact and mass extinctions: incredible or credible coincidences?: Lithos, v. 79, pp. 299-316.

Wignall, P.B., 2001, Large igneous provinces and mass extinctions: Earth Science Reviews, v. 53, pp. 1-33.

Williams, P.J., Barton, M.D., Johnson, D.A., Fontboté, L., De Haller, A., Mark, G., Oliver, N.H.S., Marschik, R., 2005, Iron oxide copper-gold deposits: geology, space-time distribution, and possible modes of origin: Economic Geology 100th Anniversary Issue, pp. 371-406.

Willner, A., Schreyer, W., Moore, J.M., 1990, Peraluminous metamorphic rocks from the Namaqualand Metamorphic Complex (South Africa): geochemical evidence for an exhalation-related sedimentary origin in a MidProterozoic rift system: Chemical Geology, v. 81, pp. 221-240.

Wilson, J.T, 1963, Continental drift: Scientific American, v. 208, pp. 86-100.

Windley, B.F., 1995, The evolving continents: John Wiley \& Sons, Chichester

Wingate, M.T.D., Pirajno, F., Morris, P.A., 2004, Warakurna large igneous province: a new Mesoproterozoic large igneous province in west-central Australia: Geology, v. 32, pp. 105-108.

Wyman, D.A, Kerrich, R., Polat, A., 2002, Assembly of Archean cratonic mantle lithosphere and crust: plume-arc interaction in the Abitibi-Wawa subduction-accretion complex: Precambrian Research, v. 115, pp. 37-62.

Xia, L-Q., Xu, X-Y., Xia, Z-C., Li, X-M., Ma, Z-P., Wang, L-S., 2004, Petrogenesis of Carboniferous rift-related volcanic rocks in the Tianshan, north- western China: Geological Society of America Bulletin v. 116, pp. 419-433.

Yirgu, G., Ebiger, C.J., Maguire, P.K.H. (eds), 2006, The Afar volcanic province within the East African Rift System: Geological Society, London, Special Publication 259.

Zhao, J-X., McCulloch, M.T., Korsch, R.J., 1994, Characterisation of a plumerelated $\sim 800$ Ma magmatic event and its implications for basin formation in central-southern Australia: Earth Planetary Science Letters, v. 121, pp. 349-367.

Zhao, D-P. 2004, Global tomographic images of mantle plumes and subducting slabs: insight into deep Earth dynamics: Physics of the Earth and Planetary Interiors, v. 146, pp. 3-34.

Ziegler, P.A., Cloetingh, S., 2004, Dynamic processes controlling the evolution of rifted basins: Earth Science Reviews, v. 64, pp 1-50.

Franco Pirajno is a senior geoscientist in the Geological Survey of Western Australia. Prior to joining GSWA in 1993, Franco was Professor of Economic Geology at Rhodes University, South Africa. He is the author of two books on mineral deposits, and currently working on a third. Since 2003, Franco has also been involved in fieldwork and studies of mineral deposits in China, and the supervision of $P h D$ students from China University of Geosciences (Beijjng), where he was recently awarded an Honorary Professorship, his current duties at GSWA include studies of mineral systems in Western Australia.

\title{
CALL FOR PAPERS
}

Episodes is the quarterly science and news journal of the International Union of Geological Sciences (IUGS). It focuses on the publication of results of scientific research and other information addressing issues of interest to the global earth-science community. Special emphasis is given to topics involving geological aspects of population growth and economic development and their resulting impacts on or implications for society. As the principal publication of the IUGS, Episodes also carries information about IUGS scientific programs and activities to the extent necessary to communicate effectively with the worldwide IUGS constituency.

Contributions of the following types of manuscripts are here solicited:

- review papers

- scientific articles

- conference reports

- news and views

- letters to editor

- book reviews

- information on training courses (especially those geared to participants from developing countries)

- noteworthy new publications, including national or regional geologic maps

Episodes also invites photos or other images for the front cover. Photos must be of high technical quality and tell an interesting geological story. A color transparency and one color print (at least $9 \mathrm{~cm} \times 12.6 \mathrm{~cm}$ ) are required for submission, which should be supplemented with a short explanatory paragraph (no more than 100 words).

Please address all contributions to:

\author{
The Editor \\ Episodes \\ P. O. Box 823, 26 Baiwanzhuang Road \\ 100037 Beijing, CHINA \\ Tel: +86-10-68320827, +86-10-68329084 \\ Fax: +86-10-68328928 \\ E-mail: episodes88@yahoo.com
}

